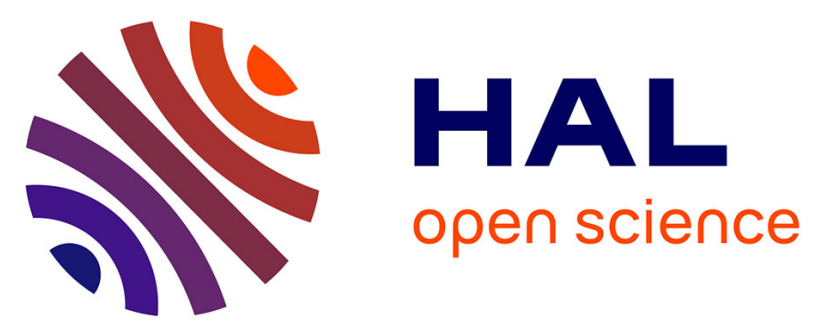

\title{
Axonal Targeting of the 5-HT1B Serotonin Receptor Relies on Structure-Specific Constitutive Activation
}

Damien Carrel, Anne Simon, Michel Emerit, Isabelle Rivals, Christophe Leterrier, Marc Biard, Michel Hamon, Michèle Darmon, Zsolt Lenkei

\section{- To cite this version:}

Damien Carrel, Anne Simon, Michel Emerit, Isabelle Rivals, Christophe Leterrier, et al.. Axonal Targeting of the 5-HT1B Serotonin Receptor Relies on Structure-Specific Constitutive Activation. Traffic, 2011, 12 (11), pp.1501-1520. 10.1111/j.1600-0854.2011.01260.x . hal-01701553

\section{HAL Id: hal-01701553 \\ https://hal.science/hal-01701553}

Submitted on 20 Apr 2018

HAL is a multi-disciplinary open access archive for the deposit and dissemination of scientific research documents, whether they are published or not. The documents may come from teaching and research institutions in France or abroad, or from public or private research centers.
L'archive ouverte pluridisciplinaire HAL, est destinée au dépôt et à la diffusion de documents scientifiques de niveau recherche, publiés ou non, émanant des établissements d'enseignement et de recherche français ou étrangers, des laboratoires publics ou privés. 


\section{Axonal Targeting of the 5- $\mathrm{HT}_{1 \mathrm{~B}}$ Serotonin Receptor Relies on Structure-Specific Constitutive Activation}

\author{
Damien Carrel 1,2,3,\#, Anne Simon ${ }^{3, \#, ~ M i c h e l ~ B . ~}$ \\ Emerit ${ }^{1,2}$, Isabelle Rivals ${ }^{4}$, Christophe \\ Leterrier $^{3,5}$, Marc Biard ${ }^{3}$, Michel Hamon ${ }^{1,2}$, \\ Michèle Darmon ${ }^{1,2, *, \dagger}$ and Zsolt Lenkei ${ }^{3, *, \dagger}$
}

\author{
${ }^{1}$ Faculté de Médecine Pierre et Marie Curie, Université \\ Pierre et Marie Curie, Site Pitié-Salpêtrière, Paris 6 \\ 2 INSERM, U894, Paris F-75013, France \\ ${ }^{3}$ Laboratoire de Neurobiologie, CNRS UMR7637, \\ ESPCI-ParisTech, Paris F-75005, France \\ ${ }^{4}$ Équipe de Statistique Appliquée, ESPCI-ParisTech, Paris \\ F-75005, France \\ ${ }^{5}$ Current address: INSERM U641 - Université de la \\ Méditerranée, F-13916 Marseille, France \\ *Corresponding authors: Michèle Darmon, \\ michele.darmon@inserm.fr and Zsolt Lenkei, zsolt.lenkei@ \\ espci.fr \\ \#, These authors contributed equally to this work.
}

By analogy to other axonal proteins, transcytotic delivery following spontaneous endocytosis from the somatodendritic membrane is expected to be essential for polarized distribution of axonal G-protein coupled receptors (GPCRs). However, possible contribution from constitutive activation, which may also result in constitutive GPCR endocytosis, is poorly known. Using two closely related but differentially distributed serotonin receptors, here we demonstrate higher constitutive activation and spontaneous endocytosis for the axonal $5-\mathrm{HT}_{1 \mathrm{~B}} \mathrm{R}$, as compared to the somatodendritic $5-\mathrm{HT}_{1 \mathrm{~A}} \mathrm{R}$, both in nonneuronal cells and neurons. Activation-dependent constitutive endocytosis is crucial for axonal targeting, because inverse-agonist treatment, which prevents constitutive activation, leads to atypical accumulation of newly synthesized $5-\mathrm{HT}_{1 \mathrm{~B}} \mathrm{Rs}$ on the somatodendritic plasma membrane. Using receptor chimeras composed of different domains from $5-\mathrm{HT}_{1 \mathrm{~A}} \mathrm{R}$ and $5-\mathrm{HT}_{1 \mathrm{~B}} \mathrm{R}$, we show that the complete third intracellular loop of $5-\mathrm{HT}_{1 \mathrm{~B}} R$ is necessary and sufficient for constitutive activation and efficient axonal targeting, both sensitive to inverse-agonist treatment. These results suggest that activation and targeting of $5-\mathrm{HT}_{1 \mathrm{~B}} \mathrm{Rs}$ are intimately interconnected in neurons.

Key words: axon, constitutive activity, polarized distribution, targeting, third intracellular loop, 7-transmembrane receptor, p11

Received 2 July 2010, revised and accepted for publication 28 July 2011, uncorrected manuscript published online 1 August 2011, published online 6 September 2011

The highly polarized neuronal plasma membrane is divided by the axon initial segment, acting as a diffusion barrier, into two functionally different main sub-domains, the axonal and somatodendritic compartments $(1,2)$. Polarized sorting mechanisms to the axonal and somatodendritic surface have been studied using model proteins, mainly cell adhesion molecules (3-7). Axonal targeting of these proteins relies either on trans-Golgi network (TGN)-based sorting via still poorly understood signals and machinery, or on endocytic removal of misplaced proteins from the somatodendritic plasma membrane, followed by degradation or by signal-mediated recycling to the axon from somatodendritic endosomes (reviewed in 8).

The superfamily of G-protein coupled receptors (GPCRs) regroups hundreds of sensory proteins, which regulate vital physiological functions and represent eminent therapeutic targets. GPCRs are highly dynamic, composed of a core of relatively rigid transmembrane alpha helices connected by flexible loops, and display a conformational equilibrium at the plasma membrane at steady state. Evidence from both functional and biophysical studies suggests that GPCRs permanently sample multiple conformations but most are held in a basal conformational equilibrium by intervening loops and non-covalent intramolecular interactions (9). Agonist and partial agonist ligands shift the equilibrium toward activated states, whereas inverse agonists shift the equilibrium toward the inactive states. Adoption of an activated state leads to the rearrangement of the cytoplasmic side of the receptor, leading to mobilization of intracellular signaling pathways mainly through a cognate heterotrimeric G-protein and also to interaction with different other protein partners, resulting in phosphorylation-dependent desensitization and ultimately in clathrin-mediated endocytosis (10).

Numerous GPCRs exhibit polarized distribution on the neuronal plasma membrane. This polarization critically determines the physiological effects that follow their activation. While several determinants of dendritic localization have been recently identified, the mechanisms responsible for axonal GPCR targeting and localization remain for the most part unknown (8). We recently proposed constitutive somatodendritic endocytosis followed by transcytotic delivery to the axonal plasma membrane for an axonal GPCR, the type-1 cannabinoid receptor (11). However, the involvement of steady-state receptor activation, an important regulator of constitutive GPCR endocytosis (12-17), is still under debate (18); thus, the relation between axonal targeting and receptor conformations triggering activation-dependent endocytosis is poorly known.

Serotonin (5-HT) receptors play key roles in cognition, mood and pathological situations such as psychosis 

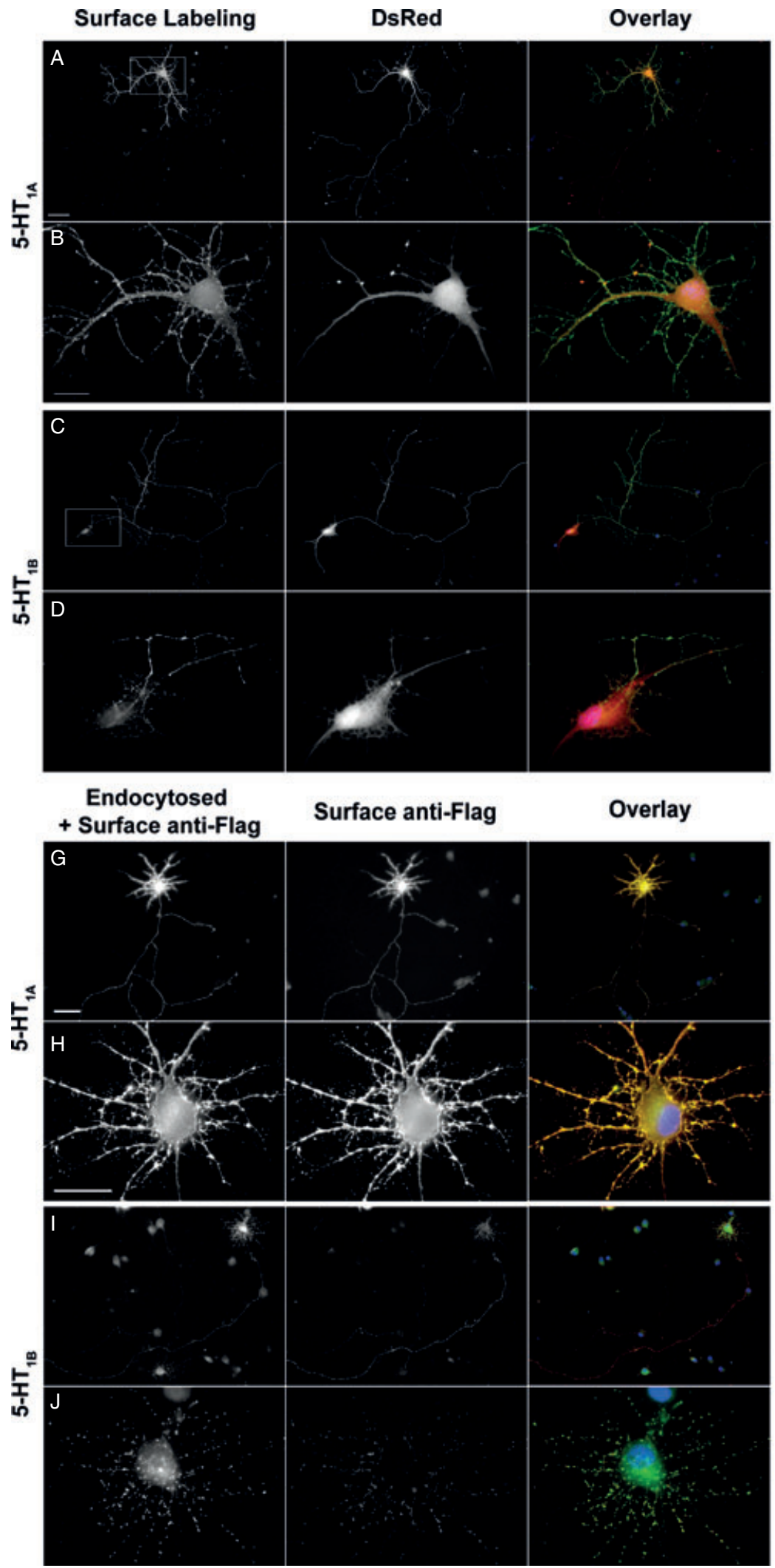
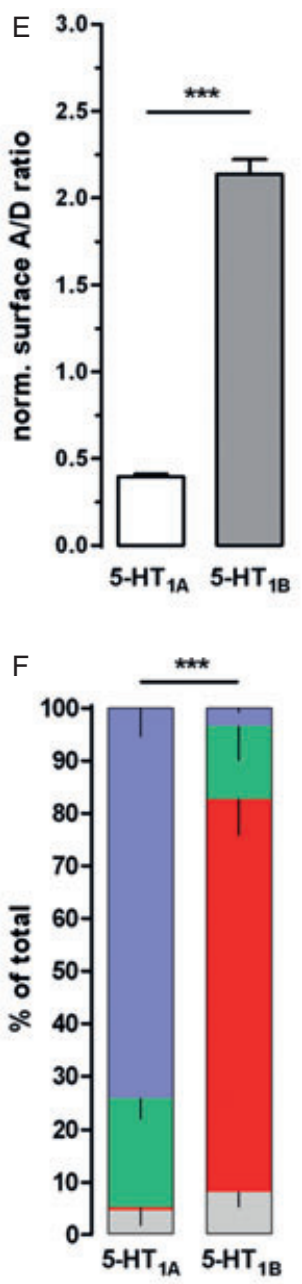

Somatodendritic Uniform

Axonal

No labeling

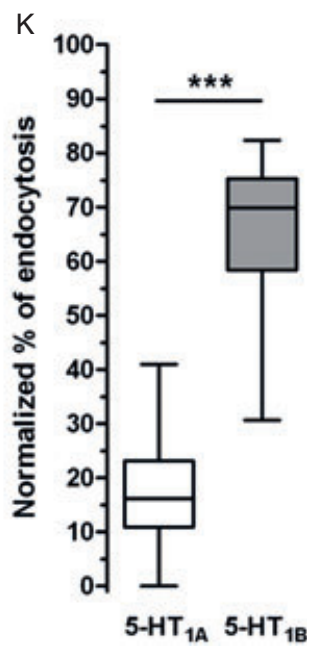

Figure 1: Legend on next page. 
Constitutive Endocytosis Targets $5-\mathrm{HT}_{1 \mathrm{~B}} \mathrm{R}$ to Axons

by regulating transmitter release, synaptic integrity and neural plasticity $(19,20)$. The $5-\mathrm{HT}_{1 \mathrm{~A}}$ and $5-\mathrm{HT}_{1 \mathrm{~B}}$ serotonin receptors are two closely related GPCRs, which are coupled to $\mathrm{G}_{\mathrm{i} / \mathrm{o}}$ proteins and mobilize similar signaling pathways (21). In neurons, both have autoreceptor functions but differ in the mechanism by which they control serotonin release. Whereas $5-H_{1} T_{1 A} R$ modulates the firing of serotonergic neurons in the raphe nuclei (22), the $5-\mathrm{HT}_{1 \mathrm{~B}} \mathrm{R}$ participates in a local control of serotonin release from axon terminals in their projection areas (19). This functional difference is governed by differential subcellular distribution of these two receptors in neurons. Investigation by specific radioligand binding, in situ hybridization, immunohistochemistry and immuno-electron microscopy showed that $5-\mathrm{HT}_{1 \mathrm{~A}} \mathrm{R}$ is mainly localized on the somatodendritic plasma membrane, whereas the $5-\mathrm{HT}_{1 \mathrm{~B}} \mathrm{R}$ is located in the plasma membrane of unmyelinated axons, mostly outside of terminals and synaptic differentiations, and is also found in cytoplasmic vesicles in the somatodendritic region (23-27). Previously, a comparative study of $5-\mathrm{HT}_{1 \mathrm{~B}} \mathrm{R}$ and $5-\mathrm{HT}_{1 \mathrm{~A}} \mathrm{R}$ targeting using chimeras of the two serotonin receptors showed that the third intracellular loop (I3) is important for the axonal targeting of $5-H T_{1 B} R(28,29)$. However, the mechanism by which the third intracellular loop regulates axonal targeting of $5 \mathrm{HT}_{1 \mathrm{~B}} \mathrm{R}$ remain unknown. More generally, it is not known whether $5 \mathrm{HT}_{1 \mathrm{~B}} \mathrm{R}$ is targeted to the axonal surface through a direct, post-TGN sorting mechanism or by the indirect, somatodendritic-endocytosis-driven transcytotic targeting pathway. Given the paucity of data regarding axonal GPCR targeting, answering these questions may yield important insights into general features of axonal targeting and also help to understand the mechanisms of a key functional feature, physiologically relevant subneuronal distribution, for the therapeutically important GPCR family.

In this study, we compared plasma membrane targeting of the $5-\mathrm{HT}_{1 \mathrm{~B}} \mathrm{R}$ and the closely related $5-\mathrm{HT}_{1 \mathrm{~A}} \mathrm{R}$ in cultured hippocampal neurons, the established a model system to study sub-neuronal targeting. By using receptor chimeras composed of different domains of $5-\mathrm{HT}_{1 \mathrm{~A}} \mathrm{R}$ and $5-\mathrm{HT}_{1 \mathrm{~B}} \mathrm{R}$, we have focused our investigation on the specific role of the third intracellular loop of $5-\mathrm{HT}_{1 \mathrm{~B}} \mathrm{R}$.

\section{Results}

\section{Axonal localization of $5-H T_{1 B} R$ is a result of constitutive somatodendritic endocytosis}

In neurons, both in vitro and in vivo data indicate that $5-\mathrm{HT}_{1 \mathrm{~B}} \mathrm{Rs}$ are localized at the axonal plasma membrane, whereas $5-\mathrm{HT}_{1 \mathrm{~A}} \mathrm{R}$ are mainly localized at plasma membrane of soma and dendrites $(27,29)$. We have directly compared the surface localization of transfected $5-\mathrm{HT}_{1 \mathrm{~A}} \mathrm{R}$ and $5-\mathrm{HT}_{1 \mathrm{~B}} \mathrm{R}$, tagged with a short, eight-aminoacid-long Flag-epitope at the extracellular N-terminus, in low-density primary cultures of living hippocampal neurons (Figure 1A-D). Receptor surface localization was analyzed using two quantification methods. First, the ratio of axonal versus somatodendritic surface labeling ( $A / D$ ratio) was measured for individual transfected neurons. In addition, transfected neurons were systematically searched and classified according to the distribution of surface receptor by an investigator blind to the experimental condition (see Materials and Methods for details). Both approaches clearly showed that while there is a constant proportion of uniformly labeled neurons, $5-\mathrm{HT}_{1 \mathrm{~B}} \mathrm{R}$ is predominantly localized to the axonal surface, whereas $5-\mathrm{HT}_{1 \mathrm{~A}} \mathrm{R}$ is mostly restricted to the surface of the soma and dendrites (Figures 1E,F and S1), indicating that correct sub-neuronal targeting is a cell-autonomous feature which is well conserved in this classical model system.

Next, we investigated whether $5-\mathrm{HT}_{1 \mathrm{~B}} \mathrm{R}$ s reach the axonal plasma membrane by the indirect, transcytotic targeting pathway. This pathway was previously described for a handful of axonal proteins such as the NgCAM adhesion molecule, the GPCR CB1 cannabinoid receptor, the TrkA neurotrophin receptor or the Caspr2 protein $(6,11$, $18,30,31)$. The common hallmark of this addressing

\footnotetext{
Figure 1: $5-\mathrm{HT}_{1 \mathrm{~A}}$ and $5-\mathrm{HT}_{1 \mathrm{~B}}$ receptors display different subcellular localization and spontaneous endocytosis in cultured hippocampal neurons. A-D) Flag-5- $\mathrm{HT}_{1 \mathrm{~A}}$ or Flag-5- $\mathrm{HT}_{1 \mathrm{~B}}$ receptors were co-transfected with soluble DsRed (red), and surface-localized $5-\mathrm{HT}$ receptors (green) were detected in live cells with $\mathrm{M} 2$ anti-Flag antibody after $24 \mathrm{~h}$ of expression. Flag-5- $\mathrm{HT}_{1 \mathrm{~A}}$ (A and B) is mainly localized at the somatodendritic surface, whereas Flag-5- $\mathrm{HT}_{1 \mathrm{~B}}(\mathrm{C}$ and $\mathrm{D})$ is mainly localized at the axonal surface of neurons. $\left.\mathrm{E}\right)$ Quantification of the normalized A/D ratio (labeling intensities in axons over dendrites for surface receptor, after background correction; green channel) for individual neurons in each condition ( $n=67$ neurons pooled from three independent experiments). Values are mean \pm SEM. F) Quantification of surface distribution of Flag-5- $\mathrm{HT}_{1 \mathrm{~A}}$ and Flag-5- $\mathrm{HT}_{1 \mathrm{~B}}$ receptors after $24 \mathrm{~h}$ of expression in transfected neurons. The proportion of each category was determined for each condition as described in the experimental procedures. $\mathrm{Flag}-5-\mathrm{HT}_{1 \mathrm{~A}}$ shows a predominantly somatodendritic distribution, whereas Flag-5- $\mathrm{HT}_{1 \mathrm{~B}}$ is mainly axonal. Results are mean $\pm \mathrm{SEM}$ per category and represent data from four pooled independent experiments. The p-value for the significance of the difference between the two surface distributions was computed using Pearson's $\chi^{2}$ homogeneity test. G-J) DIV8 neurons expressing Flag-5- $\mathrm{HT}_{1 \mathrm{~A}}$ or Flag-5-HT $1 \mathrm{~B}$ were fed for $1 \mathrm{~h}$ at $37^{\circ} \mathrm{C}$ (permissive for endocytosis) with anti-Flag M2 antibody pre-coupled with goat anti-mouse antibody (green) and incubated for $1 \mathrm{~h}$ at $4^{\circ} \mathrm{C}$ (non-permissive for endocytosis) with anti-goat antibody (red). Using this method, internalized receptors are labeled in green and surface-localized receptors are labeled in yellow on the overlay image (see Materials and Methods for details). After fixation, green labeling shows that Flag-5- $\mathrm{HT}_{1 \mathrm{~B}}$ (I and J panels), but not Flag-5- $\mathrm{HT}_{1 \mathrm{~A}}$ ( $\mathrm{G}$ and $\mathrm{H}$ panels) is constitutively endocytosed in the somatodendritic compartment. K) Quantification of Flag-5- $\mathrm{HT}_{1 \mathrm{~A}}$ and Flag-5- $\mathrm{HT}_{1 \mathrm{~B}}$ receptors endocytosis. Values are presented as boxplots and represent data from at least three pooled independent experiments. On overlay images, blue represents nuclei. ${ }^{* * *} p<0.001 . A$, C, G, I, scale bar: $50 \mu \mathrm{m} ; \mathrm{B}, \mathrm{D}, \mathrm{H}, \mathrm{J}$, scale bar: $20 \mu \mathrm{m}$.
} 
mechanism is a constitutive somatodendritic endocytosis at steady state, which is followed by anterograde axonal transport of recycled proteins. We thus monitored constitutive endocytosis of Flag-tagged $5-\mathrm{HT}_{1 \mathrm{~A}} \mathrm{R}$ and $5-\mathrm{HT}_{1 \mathrm{~B}} \mathrm{R}$ during $1 \mathrm{~h}$ by incubating living hippocampal neurons successively with the anti-Flag antibody pre-coupled with an Alexa488-labeled secondary antibody at $37^{\circ} \mathrm{C}$ and then with anti-goat Alexa568 antibody at $4^{\circ} \mathrm{C}$ for $1 \mathrm{~h}$ before fixation. Using this approach, receptors which were accessible at the cell surface during the first 1-h incubation period at $37^{\circ} \mathrm{C}$ were labeled in green. Therefore, the green label identifies two receptor populations, those that were endocytosed and those that remained at the cell surface, while only receptors remaining at the cell surface are co-labeled in red (resulting in yellow on the overlay image) during the second incubation period at $4^{\circ} \mathrm{C}$, a nonpermissive temperature for endocytosis. The ratio of the red and green labels indicates the relative level of receptor endocytosis (see Materials and Methods for details). We found prominent green labeling of intracellular vesicles in the somatodendritic compartment of neurons transfected with $5-\mathrm{HT}_{1 \mathrm{~B}} \mathrm{R}$ (Figure $1 \mathrm{I}, \mathrm{J}$ ) but not in the neurons transfected with $5-\mathrm{HT}_{1 \mathrm{~A}} \mathrm{R}$ (Figure $1 \mathrm{G}, \mathrm{H}$ ), as confirmed by quantification (Figure 1K). The extent of internalization was independent of the expression level $\left(r^{2}=0.06\right.$ for $5-\mathrm{HT}_{1 \mathrm{~A}} \mathrm{R}$ and 0.09 for $5-\mathrm{HT}_{1 \mathrm{~B}} \mathrm{R}$; Figure $\left.\mathrm{S} 1 \mathrm{C}\right)$. These results indicate significant constitutive endocytosis for $5-\mathrm{HT}_{1 \mathrm{~B}} \mathrm{R}$ but not 5-HT $1 \mathrm{~A}$ R.

To investigate the role of this steady-state endocytosis in axonal targeting of $5-\mathrm{HT}_{1 \mathrm{~B}} \mathrm{R}$, we then coexpressed the receptor with wild-type (WT) and dominant-negative mutants of endocytic proteins, and measured the A/D ratio of surface receptors. We studied the effects of dominantnegative mutants of eps 15 and dynamin-2 (Figures 2 and S2). Eps15 is an AP-2 binding protein that is involved in clathrin-mediated endocytosis (32), whereas dynamin-2 GTPase participates in the last step of endocytosis by pinching the vesicle from the plasma membrane (33). Coexpression of enhanced cyan fluorescent protein (eCFP)-labeled control constructs (eps15(DIII $\Delta 2$ ) and dyn2(WT), Figure S2A,C) did not modify the distribution of surface $5-\mathrm{HT}_{1 \mathrm{~B}} \mathrm{R}$ (Figure $2 \mathrm{~F}$ ) compared to transfection of $5-\mathrm{HT}_{1 \mathrm{~B}} \mathrm{R}$ alone. Contrastingly, in the presence of dominant-negative forms of eps 15 or dynamin-2, the surface expression of $5-\mathrm{HT}_{1 \mathrm{~B}} \mathrm{R}$ was increased in dendrites and reduced in axons, leading to a significant decrease of the A/D surface labeling ratio and to a pronounced somatodendritic distribution of $5-\mathrm{HT}_{1 \mathrm{~B}} \mathrm{R}$ (Figures $2 \mathrm{~A}, \mathrm{D}^{\prime}, \mathrm{E}^{\prime}, \mathrm{F}$ and $S 2 B, D)$, leading to a distribution very similar to that of $5-\mathrm{HT}_{1 \mathrm{~A}} \mathrm{R}$ (Figures $1 \mathrm{~A}$ and $2 \mathrm{~F}$ ). A striking example is shown in Figure 2, where two neighboring neurons on the same coverslip show a fortuitous difference of co-transfection efficiency with eCFP-labeled dominantnegative eps15. The neuron expressing a relatively high level of eps15( $\Delta$ 95-295)-eCFP (zoomed in Figure 2B'-E') shows a complete reversal of distribution polarity. These results indicate a crucial role for constitutive somatodendritic endocytosis in the axonal targeting of $5-\mathrm{HT}_{1 \mathrm{~B}} \mathrm{R}$.
5-HT $T_{1 B} R$ s but not $5-H T_{1 A} R$ s are constitutively internalized also in non-neuronal cells as a result of constitutive activation

To investigate whether the above-described differences in constitutive endocytosis of $5-\mathrm{HT}_{1 \mathrm{~A}} \mathrm{R}$ and $5-\mathrm{HT}_{1 \mathrm{~B}} \mathrm{R}$ are characteristic to neurons or are a general feature of these two receptors independent of the precise cellular context, we analyzed their subcellular localization in transfected LLC-PK1 cells. To directly visualize and quantify the subcellular distribution of $5-H_{1 A} R$ and $5-H T_{1 B} R$, we fused the fluorescent protein eGFP (enhanced green fluorescent protein) to the intracellular $C$ terminus of both receptors. We tested the functional parameters of eGFPtagged and -untagged receptors in transfected LLC-PK1 cells (Figure S3). First, we observed that agonist 5-CT efficiently stimulated $\left[{ }^{35} \mathrm{~S}\right.$ ] GTP $\gamma \mathrm{S}$ binding to both native and eGFP-tagged receptors, but that addition of eGFP modified to some extent the amplitude of the responses, which was decreased for $5-\mathrm{HT}_{1 \mathrm{~A}} \mathrm{R}(\mathrm{p}<0.001)$ and increased for $5-\mathrm{HT}_{1 \mathrm{~B}} \mathrm{R}(\mathrm{p}=0.0024$, Figure S3B), suggesting that the eGFP tag may interfere with the coupling efficacy of Gproteins. However, addition of eGFP to the receptors did not modify ligand-binding affinity (Figure S3A) and preserved the qualitative profile (Figure S3B) of the response of both receptors to agonist and inverse-agonist treatments (see below), suggesting that the eGFP tag at the C-terminal does not change qualitatively the steady-state conformational state of the receptors.

As we previously observed using Flag-tagged receptors (34), 5-HT $1 \mathrm{~A}-\mathrm{eGFP}$ was predominantly localized to the plasma membrane, whereas $5-\mathrm{HT}_{1 \mathrm{~B}}-\mathrm{eGFP}$ presented a prominent intracellular localization (Figure 3A). In these experiments, cells were treated with the protein synthesis inhibitor cycloheximide; thus, it is improbable that the high level of intracellular labeling is due to receptors in the neo-synthetic pathway. To investigate if intracellular receptors are of endocytic origin, we used acute depletion of plasma membrane cholesterol using methyl- $\beta$-cyclodextrin (M $\beta C D)$, a method which was shown to efficiently inhibit clathrin-dependent endocytosis, but not recycling of the transferrin receptor (35), the cannabinoid CB1 receptor $(11,13)$ and the amyloid precursor protein $(36)$. After incubation with $10 \mathrm{mM} M \beta C D$ for $1 \mathrm{~h}, 5-\mathrm{HT}_{1 \mathrm{~B}}-\mathrm{eGFP}$ was accumulated at the plasma membrane of transfected LLCPK1 cells (Figure 3A,B). In contrast, the same treatment did not significantly modify the localization of $5-\mathrm{HT}_{1 \mathrm{~A}^{-}}$ eGFP, as confirmed by quantification of the membrane fluorescence ratio (MFR). These data support the idea that intracellular localization of $5-\mathrm{HT}_{1 \mathrm{~B}} \mathrm{R}$ depends on constitutive endocytosis also in non-neuronal cells.

Because $5-\mathrm{HT}_{1 \mathrm{~B}} \mathrm{R}$ shows constitutive activation of signaling pathways in the absence of agonist in transfected cell lines $(37,38)$, we investigated the potential correlation of this particular feature with constitutive endocytosis of $5-\mathrm{HT}_{1 \mathrm{~B}} \mathrm{R}$. We first investigated the constitutive Gprotein activation capacity of native and eGFP-tagged receptors stably expressed in LLC-PK1 cells by the 

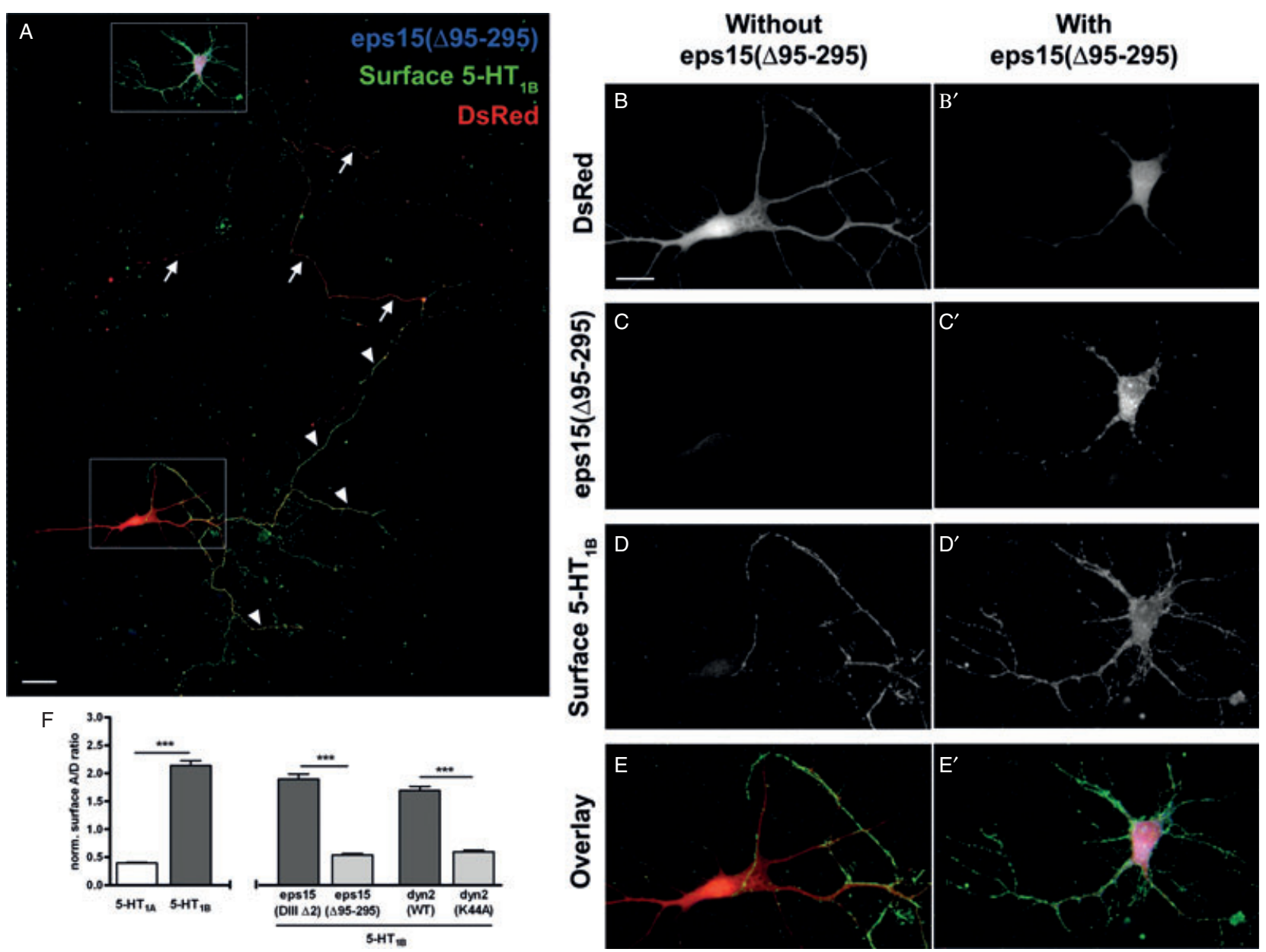

Figure 2: Inhibition of neuronal endocytosis shifts surface expression of $5-\mathrm{HT}_{1 \mathrm{~B}} \mathrm{R}$ from the axon to the soma and dendrites. Hippocampal neurons at DIV7 were co-transfected with soluble DsRed, Flag-5-HT $1 \mathrm{~B}$ and a fusion of eCFP (blue) with various proteins: inactive mutant eps15(III $\Delta 2$ ) or dominant-negative eps15( $\Delta 95-295)$, wild-type dynamin2(WT) or dominant-negative dynamin2(K44A). Twenty-four hours later, they were stained for surface $5-\mathrm{HT}_{1 \mathrm{~B}} \mathrm{R}$ (green) and fixed. WT or inactive proteins did not change polarization of $5-\mathrm{HT}_{1 \mathrm{~B}} \mathrm{R}$ surface expression (green labeling, F), whereas dominant-negative mutants of eps 15 and dyn2 strongly upregulated expression of $5-\mathrm{HT}_{1 \mathrm{~B}} \mathrm{R}$ at the somatodendritic surface (F). In $\mathrm{A}-\mathrm{E}^{\prime}$ are shown two neighboring neurons from the same coverslip. The neuron at the top has been successfully co-transfected with Flag-5- $\mathrm{TT}_{1 \mathrm{~B}} \mathrm{R}$ and the dominant-negative eps $15(\Delta 95-295)$ (as shown by the CFP expression $-C^{\prime}$ ) and presents a strong somatodendritic surface labeling ( $D^{\prime}$ and $E^{\prime}$ ) coupled to a barely observable axonal surface labeling (arrows). On the other hand, the neuron at the bottom, because of the variability of co-transfection efficiency, does not express dominant-negative eps15( $\Delta 95-295)$ (C) and shows a correct localization of the receptors at the axonal surface (arrowheads, A, D, E). F) Quantification of the normalized A/D ratio as described in Figure 1 and Materials and methods ( $n=41-67$ neurons pooled from three independent experiments). Values of Flag-5-HT $\mathrm{HT}_{1 \mathrm{~A}}$ and Flag-5- $\mathrm{HT} \mathrm{T}_{1 \mathrm{~B}}$ are a reminder of Figure $1 \mathrm{E}$. Values are mean $\pm \mathrm{SEM} ;{ }^{* * *} \mathrm{p}<0.001$. A, scale bar: $50 \mu \mathrm{m}$; B-E', scale bar: $20 \mu \mathrm{m}$.

use of inverse agonists, which promote the adoption of inactive receptor states. Addition of the inverse agonist SB224289 (38) significantly reduced basal [ ${ }^{35}$ S]GTP $\gamma$ S binding for $5-\mathrm{HT}_{1 \mathrm{~B}}$ and $5-\mathrm{HT}_{1 \mathrm{~B}}-\mathrm{eGFP}$ receptors (Figure $\mathrm{S} 3 \mathrm{~B}$ ), indicating that both constructs have an elevated constitutive activity. In comparison, the 5- $\mathrm{HT}_{1 \mathrm{~A}} \mathrm{R}$ inverse agonist methiothepin led to a moderate but non-significant reduction of basal $\left.{ }^{35} \mathrm{~S}\right] \mathrm{GTP} \gamma \mathrm{S}$ binding for native $5-\mathrm{HT}_{1 \mathrm{~A}}$ receptors $[p>0.05$ versus vehicle by Newman-Keuls post-test following one-way analysis of variance (ANOVA)] and no reduction was observed for $5-\mathrm{HT}_{1 A}-\mathrm{eGFP}$. We next examined the effects of respective inverse agonists on subcellular localization of eGFP-tagged receptors in the same stably transfected LLC-PK1 cells (Figure 3A,B). Figure 3B shows that SB224289 was able to significantly externalize $5-\mathrm{HT}_{1 \mathrm{~B}}$-eGFP at the plasma membrane, similar to the endocytosis inhibitor $M \beta C D$, as reported above. In contrast, $5-\mathrm{HT}_{1 \mathrm{~A}}-\mathrm{eGFP}$ localization was not modified after incubation with methiothepin (Figure 3B) or spiperone, another $5-\mathrm{HT}_{1 \mathrm{~A}} \mathrm{R}$ inverse agonist (data not shown). Collectively, these results show that constitutive endocytosis of $5-\mathrm{HT}_{1 \mathrm{~B}} \mathrm{R}$ results from spontaneous adoption of the active receptor conformation, which also leads to parallel constitutive activation of G-proteins in non-neuronal cells. 
Carrel et al.
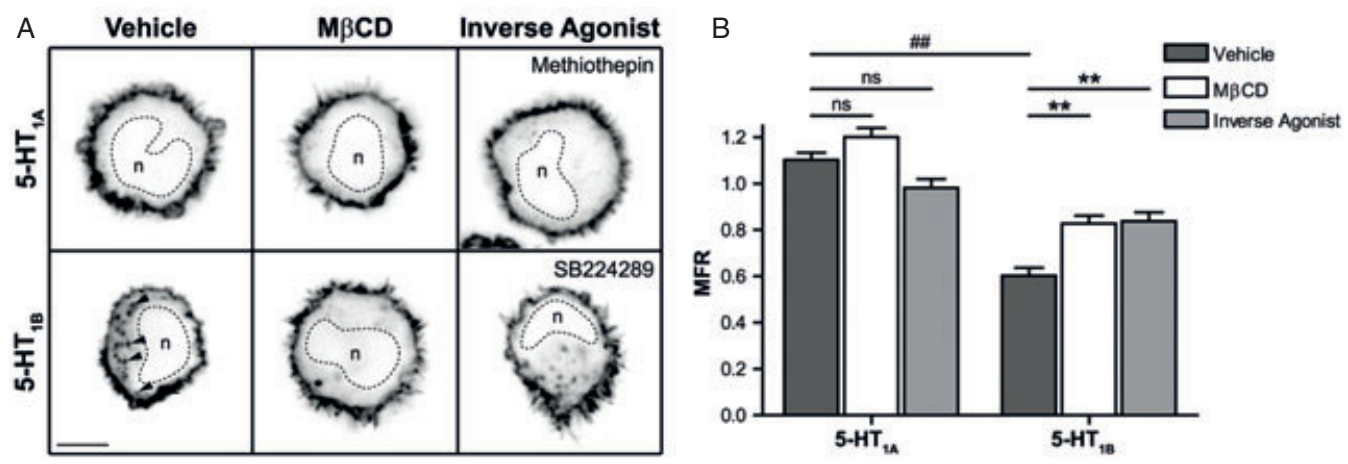

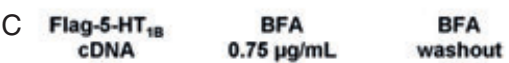

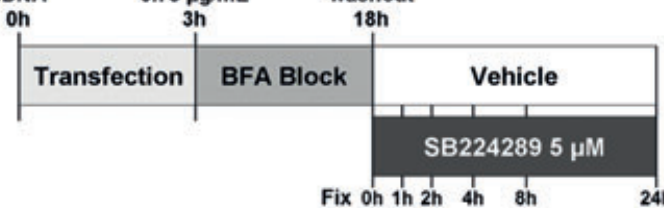

D

Vehicle

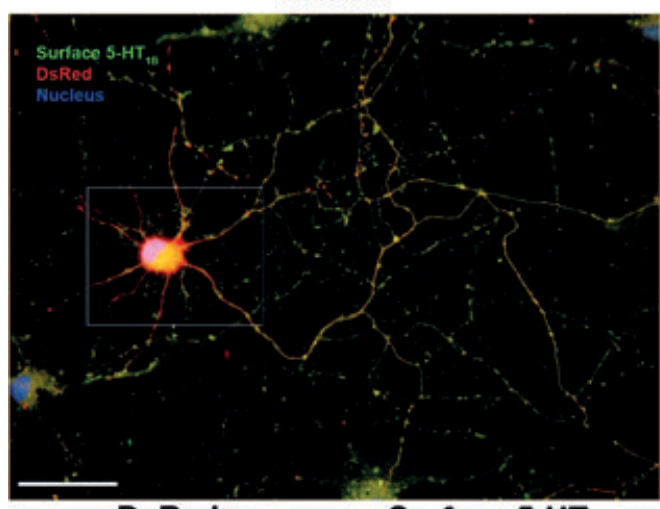

DsRed

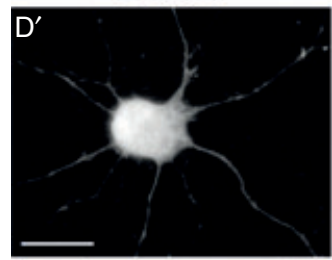

$\mathrm{D}^{\prime \prime}$

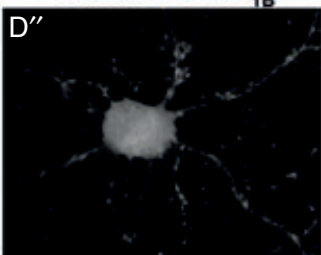

F

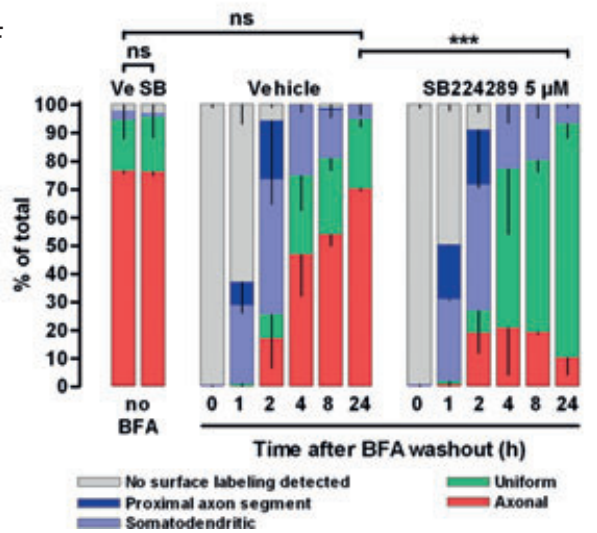

Axonal Proximal axon segment

Figure 3: Legend on next page.
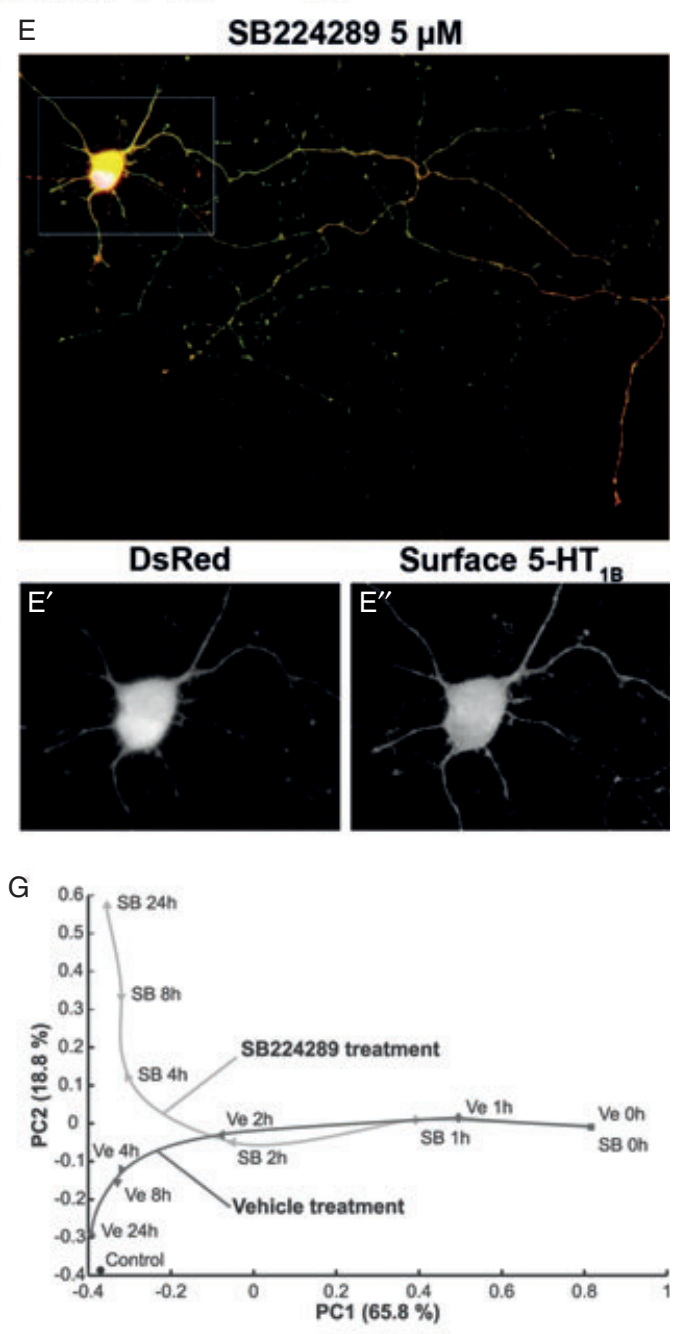


\section{Constitutive-activation-dependent endocytosis} is necessary for the axonal targeting of $5-H T_{1 B} R$

To investigate the role of the above-described constitutiveactivation-dependent endocytosis in axonal targeting, we followed the kinetics of plasma membrane insertion of $5-\mathrm{HT}_{1 \mathrm{~B}} \mathrm{Rs}$ in the absence or the presence of the inverse agonist SB224289 by using a Brefeldin A (BFA) release protocol (6). BFA reversibly inhibits Arf1-dependent intracellular transport, blocking export of membrane proteins that accumulate in a mixed endoplasmic reticulum (ER)/Golgi compartment. After washout of BFA, protein trafficking resumes in a synchronized manner, inducing a 'pulse' of protein export and targeting to their functional subcellular compartments. Neurons were transfected with Flag-5- $\mathrm{HT}_{1 \mathrm{~B}}$ for $3 \mathrm{~h}$, treated overnight with BFA, then allowed to resume protein trafficking by washing out BFA in the presence of vehicle or inverse agonist SB224289 and fixed at different times after washout $(0,1,2,4$, 8 or 24 h, Figure $3 C$ ). Live staining of surface receptors was performed by rapid incubation with anti-Flag antibody preceding fixation and staining with secondary antibody. Transfected neurons were then classified according to the distribution of surface $5-\mathrm{HT}_{1 \mathrm{~B}} \mathrm{R}$. In control cells with no BFA block, $78.3 \pm 1.5 \%$ of transfected neurons exhibited axonal distribution of $5-\mathrm{HT}_{1 \mathrm{~B}} \mathrm{R}$ (Figure $3 \mathrm{~F}$ ). Immediately after BFA washout, no surface $5-\mathrm{HT}_{1 \mathrm{~B}} \mathrm{R}$ was observed. However, $1 \mathrm{~h}$ after BFA washout, a significant proportion of neurons showed somatodendritic surface staining $(27.9 \pm 1.9 \%)$ or a very particular staining restricted to the surface of the proximal axon segment $(8.4 \pm 5.6 \%)$.
This latter localization pattern disappeared after $2 \mathrm{~h}$, while somatodendritic surface staining reached a peak with $47.9 \pm 4.4 \%$ of neurons displaying somatodendritic surface staining at that time. This proportion then decreased as the proportion of neurons showing axonal surface staining increased to reach the pattern observed in the untreated neurons $24 \mathrm{~h}$ after washout, with a majority of neurons now displaying a predominantly axonal distribution $(70.4 \pm 0.6 \%$, Figure 3D,F). The transient appearance of $5-\mathrm{HT}_{1 \mathrm{~B}} \mathrm{R}$ at the somatodendritic surface suggests that these receptors are not directly targeted to axons but are rather non-specifically sent toward the entire neuronal plasma membrane. Thus, most of them appear first on the somatodendritic membrane from where they are subsequently removed by constitutive endocytosis, whereas receptors reaching the axonal surface are maintained on this plasma membrane sub-compartment. Strikingly, when BFA washout was followed by incubation with the inverse agonist SB224289, which stabilizes the inactive receptor conformation, the final surface distribution of 5$\mathrm{HT}_{1 \mathrm{~B}} \mathrm{R}$ was substantially modified (Figure 3E,F). Although the receptor appeared $1 \mathrm{~h}$ after washout on the somatodendritic surface, subsequent polarization of receptor distribution was impaired by SB224289, leading to neurons displaying mostly uniform distribution at $24 \mathrm{~h}$ after washout $(83.1 \pm 3.7 \%)$. The difference in surface insertion of $5-\mathrm{HT}_{1 \mathrm{~B}} \mathrm{R}$ during vehicle and SB224289 treatments was analyzed by principal component analysis (PCA) of the receptor surface distribution. PCA is an unsupervised method for the analysis of multidimensional data that

Figure 3: $5-\mathrm{HT}_{1 \mathrm{~B}} \mathrm{R}$ targeting to the axonal plasma membrane relies on constitutive activity-dependent constitutive endocytosis. $A$ and B) Subcellular distribution of $5-\mathrm{HT}_{1 \mathrm{~B}} \mathrm{R}$ but not $5-\mathrm{HT}_{1 \mathrm{~A}} \mathrm{R}$ is modified by inhibition of endocytosis through acute depletion of plasma membrane cholesterol or by inhibition of constitutive activity by treatment with an inverse agonist. A) Confocal images of equatorial sections of morphologically standardized near-spherical LLC-PK1 cells expressing 5-HT1A-eGFP or 5-HT $1 \mathrm{~B}-\mathrm{eGFP}$, and fixed after incubation at $37^{\circ} \mathrm{C}$ with vehicle, $10 \mathrm{mM} \mathrm{MBCD}$ for acute depletion of plasma membrane cholesterol, $1 \mu \mathrm{M}$ inverse agonist methiothepin (5-HT $1 \mathrm{~A}$ ) or SB224289 $\left(5-\mathrm{HT}_{1 \mathrm{~B}}\right)$. Arrowheads show the endosomal localization of vehicle-treated $5-\mathrm{HT}_{1 \mathrm{~B}}-\mathrm{eGFP}$. ' $\mathrm{n}$ ' - nucleus. Scale bar, $5 \mu \mathrm{m}$. B) Quantification of the MFR (ratio of the corrected total fluorescence of surface versus cytoplasm, as described under Materials and Methods) for both receptors after treatment with vehicle, M $\beta C D$ or inverse agonist. Results are mean \pm SEM and represent data from at least two pooled independent experiments ( $n=32-48$ cells per condition). \#\#p $<0.01$ for significance of difference between $5-\mathrm{HT}_{1 \mathrm{~A}} \mathrm{R}$ and $5-\mathrm{HT}_{1 \mathrm{~B}} \mathrm{R}$ after vehicle treatment. ${ }^{*} \mathrm{p}<0.01$ for significance between $\mathrm{M} \beta \mathrm{CD}$ or inverse-agonist treatment and vehicle; ns, non-significant. $\mathrm{C}-\mathrm{G}$ ) Time-course of $5-\mathrm{HT}_{1 \mathrm{~B}} \mathrm{R}$ insertion into the neuronal plasma membrane. C) Diagram of the time-course experiment. DIV8 neurons were co-transfected with Flag-5- $\mathrm{HT}_{1 \mathrm{~B}}$ and DsRed for a 3-h incubation in transfection medium. They were then incubated overnight with $0.75 \mu \mathrm{g} / \mathrm{mL}$ BFA to block protein export from the Golgi apparatus. After extensive washes (BFA washout), neurons were incubated in either regular medium or in the presence or $5 \mu \mathrm{M}$ inverse agonist SB224289 for 0, 1, 2, 4, 8 and $24 \mathrm{~h}$. At these time-points, neurons were labeled for surface Flag-5- $\mathrm{HT}_{1 \mathrm{~B}}$ receptors and fixed. The proportion of each category was determined for each condition and time-point as described in the experimental procedures. D-D") Flag-5- $\mathrm{HT}_{1 \mathrm{~B}}$ labeling $24 \mathrm{~h}$ after BFA washout in control condition. Flag-5- $\mathrm{HT}_{1 \mathrm{~B}}$ is correctly localized at the surface of axons. $\left.\mathrm{E}-\mathrm{E}^{\prime \prime}\right)$ Flag-5- $\mathrm{HT}_{1 \mathrm{~B}}$ labeling $24 \mathrm{~h}$ after BFA washout in the presence of $5 \mu \mathrm{M}$ SB224289. Flag-5- $\mathrm{HT}_{1 \mathrm{~B}}$ is present as a uniform surface labeling. F) Time-course of Flag-5- $\mathrm{HT}_{1 \mathrm{~B}}$ surface targeting in control and treated conditions. Right after BFA washout $(0 \mathrm{~h})$, no Flag-5- $\mathrm{HT}_{1 \mathrm{~B}}$ labeling is present at the neuronal plasma membrane. Then, for both treatment conditions, Flag-5- $\mathrm{HT}_{1 \mathrm{~B}}$ receptors transiently appear on the somatodendritic and proximal axon segment surface (at 1 and $2 \mathrm{~h}$ ). This precedes establishment of the proper axonal distribution (after $24 \mathrm{~h}$, illustrated in D-D') for untreated neurons, whereas inverse-agonist treatment (SB224289, $5 \mu \mathrm{m}$ ) inhibits the emergence of the axonal surface distribution of Flag-5- $\mathrm{HT}_{1 \mathrm{~B}}$ (majority of 'uniform' phenotype $24 \mathrm{~h}$ after BFA washout in the presence of SB224289, illustrated in E-E'). In the absence of incubation with BFA (two bars on the left), treatment with SB224289 for $8 \mathrm{~h}$ does not alter the distribution of Flag-5- $\mathrm{HT}_{1 \mathrm{~B}}$ in comparison with vehicle treatment. Results are mean \pm SEM per category and represent data from two pooled independent experiments ( $n=85-160$ neurons per condition). The p-value for the significance of the difference between couples of surface distributions was computed using Pearson's $\chi^{2}$ homogeneity test. G) PCA plot of the surface distribution of $5-\mathrm{HT}_{1 \mathrm{~B}}$ receptors for each time-point of both treatment conditions and for vehicle treatment in the absence of incubation with BFA (control). Tendency curves show distribution kinetics for both treatment conditions. On overlay images, blue represents nuclei. *** $p<0.001$; ns, non-significant. D, E: scale bar: $50 \mu \mathrm{m}$. $D^{\prime}, \mathrm{D}^{\prime \prime}, \mathrm{E}^{\prime}, \mathrm{E}^{\prime \prime}:$ scale bar: $20 \mu \mathrm{m}$. 


\section{Carrel et al.}

identifies the directions of the description space (here the distribution among the four surface distribution categories) accounting for the largest part of the data variance, called principal components. As shown in Figure 3G, which displays the projection of the data onto the subspace spanned by the two first principal components, starting from $2 \mathrm{~h}$ after the BFA release, the distribution converges clearly toward the natural receptor distribution pattern (measured in the absence of BFA block) in vehicle-treated controls, while it diverges from this control distribution during SB224289 treatment. These results suggest that adoption of an active receptor conformation is necessary for endocytic elimination of $5-\mathrm{HT}_{1 \mathrm{~B}} \mathrm{R}$ from the somatodendritic plasma membrane and for the establishment of axonal polarity.

\section{The third intracellular loop of $5-H T_{1 B} R$ is necessary and sufficient for constitutive endocytosis in non-polarized cells}

$5-\mathrm{HT}_{1 \mathrm{~A}} \mathrm{R}$ and $5-\mathrm{HT}_{1 \mathrm{~B}} \mathrm{R}$ show $43 \%$ identity in their aminoacid sequences (39). However, 5- $\mathrm{HT}_{1 \mathrm{~A}}-\mathrm{eGFP}$ receptor did not show the constitutive endocytosis and activity observed for 5- $\mathrm{HT}_{1 \mathrm{~B}}-\mathrm{e}$ GFP receptor. We thus used 5- $\mathrm{HT}_{1 \mathrm{~A}} /$ $5-H T_{1 B}$ chimeras to determine which region of $5-H T_{1 B} R$ is responsible for constitutive endocytosis. The structures of the six chimeras used are represented in Figures 4 and S4B. The chimeras are designated by a three-letter code. The first letter indicates the origin of the $\mathrm{N}$-terminal portion up to the third intracellular loop (I3), the second letter is for the origin of 13 and the third letter for the origin of the C-terminal portion downstream 13. For example, the native $5-\mathrm{HT}_{1 \mathrm{~A}}$ receptor would read $\mathrm{Aaa}$, whereas the chimera where the 13 of $5-\mathrm{HT}_{1 \mathrm{~B}}$ is replaced by the 13 of $5-\mathrm{HT}_{1 \mathrm{~A}}$ would read Bab. These chimeras were fused to eGFP at their $\mathrm{C}$ terminus and we analyzed their subcellular localization in transfected LLC-PK1 cells in the presence or absence of $\mathrm{M} \beta C D$ treatment, which inhibits spontaneous endocytosis. First, chimeras Aab and Abb did not reach plasma membrane in any condition, and were sequestrated in a perinuclear compartment (data not shown), similar to the localization previously reported for non-tagged identical chimeras, suggesting that these constructs were probably incorrectly folded (28). Chimeras Baa and Bab were localized at the plasma membrane and their MFR was not modified by the addition of M $\beta C D$ (Figure $4 A, B, E$ ). In contrast, chimeras Aba and Bba were mostly intracellular and were significantly externalized after incubation with $M \beta C D$, indicating that both constructs were constitutively endocytosed (Figure 4C,D,E).
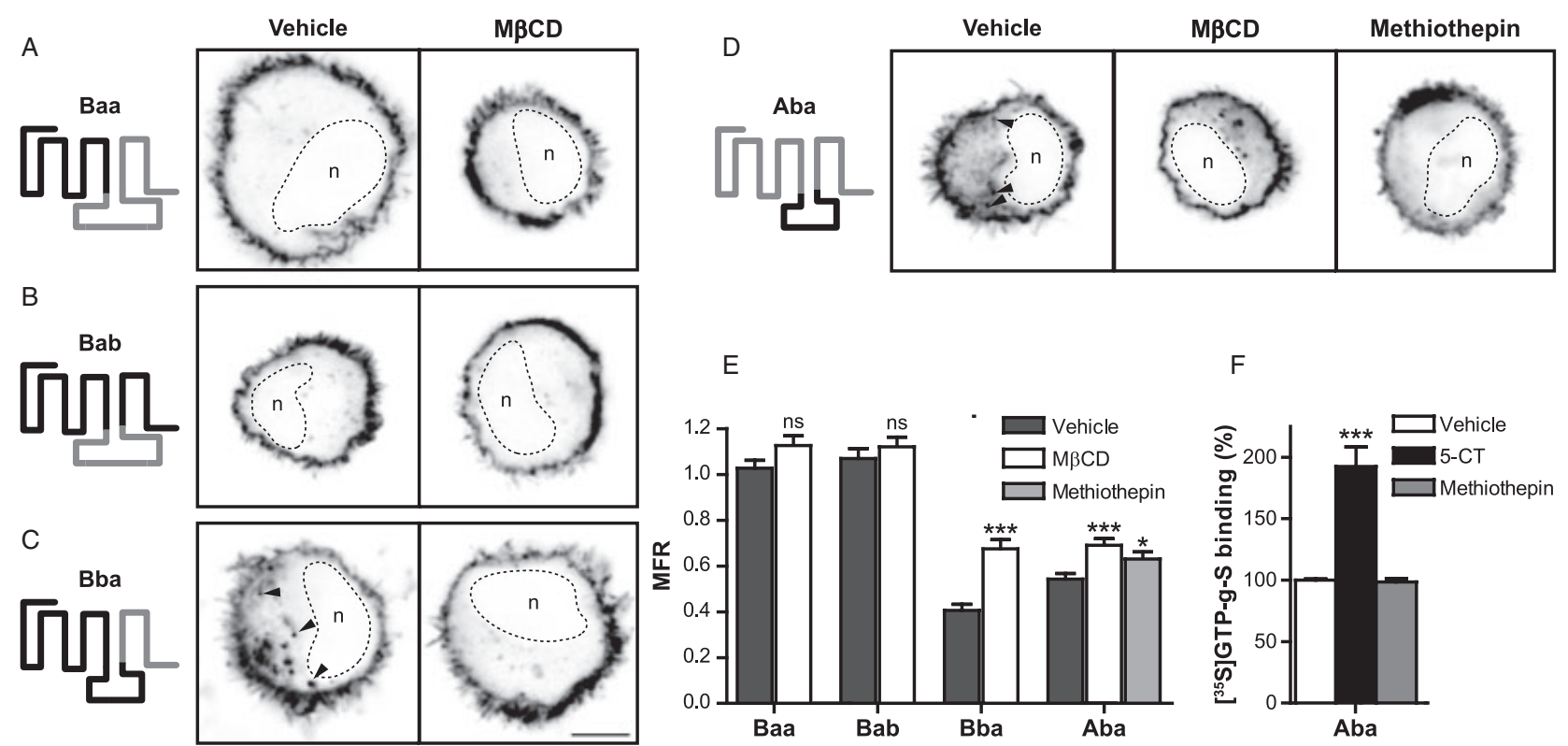

Figure 4: The third intracellular loop of $5-\mathrm{HT}_{1 \mathrm{~B}} \mathrm{R}$ induces a constitutive endocytosis of chimeric receptors that is dependent on constitutive activation, without constitutive interaction with $\mathbf{G}_{\alpha}$ protein. A-D) Confocal images of equatorial sections of morphologically standardized near-spherical LLC-PK1 cells, transfected with chimera Baa-eGFP (A), Bab-eGFP (B), Bba-eGFP (C) or Aba-eGFP (D) and fixed after incubation at $37^{\circ} \mathrm{C}$ with vehicle $(90 \mathrm{~min}), 1 \mu \mathrm{M}$ of inverse agonist methiothepin (90 min) or $10 \mathrm{mM} \mathrm{M} \beta \mathrm{CD}$ (60 $\mathrm{min}$ ) for acute depletion of plasma membrane cholesterol. The amino-acid sequence of each chimera is represented schematically, with $5-\mathrm{HT}_{1 \mathrm{~A}} \mathrm{R}$ parts in gray and $5-\mathrm{HT}_{1 \mathrm{~B}} \mathrm{R}$ parts in black. Arrowheads show the endosomal localization of vehicle-treated Bba-eGFP and Aba-eGFP chimeras. ' $n$ ' - nucleus. Scale bar, $5 \mu \mathrm{m}$. E) Quantification of the MFR for each chimera after treatment with vehicle, methiothepin or M $\beta C D$. Results are mean \pm SEM and represent data from at least two pooled independent experiments $(n=32-48$ cells for each condition). ${ }^{*} p<0.5$ and ${ }^{* * *} p<0.001$ for significance versus vehicle treatment; ns, non-significant. F) [ ${ }^{35}$ S]GTP $\gamma \mathrm{S}$ binding to membranes from LLC-PK1 cells expressing Aba-eGFP. Binding was determined in the presence of the agonist 5-CT or the inverse agonist methiothepin. Basal binding determined in the absence of ligand was set to $100 \%$. Results are mean \pm SEM of three independent experiments performed in triplicate. ${ }^{* *} \mathrm{p}<0.001$ for significance of difference between basal and 5 -CT treatment. 
These results suggest that the third intracellular loop of the receptor plays a crucial role in constitutive endocytosis. In particular, the Aba chimera obtained by replacement of $5-\mathrm{HT}_{1 \mathrm{~A}} \mathrm{R}$ I3 loop by that of $5-\mathrm{HT}_{1 \mathrm{~B}} \mathrm{R}$ presents the same level of constitutive endocytosis as $5-\mathrm{HT}_{1 \mathrm{~B}} \mathrm{R}$.

We next investigated whether constitutive endocytosis of the Aba chimera was also due to spontaneous adoption of active receptor conformation. Previous studies showed that the Aba chimera is functional and presents a ligand-binding pattern similar to that of $5-\mathrm{HT}_{1 \mathrm{~A}} \mathrm{R}(28)$, indicating that exchange of the 13 does not abolish ligand-binding specificity, which is determined by transmembrane domain residues in monoamine receptors. Strikingly, we observed that blocking constitutive activity by the $5-\mathrm{HT}_{1 \mathrm{~A}} \mathrm{R}$ inverse agonist methiothepin led to an externalization of $\mathrm{Aba}$ to the plasma membrane (Figure 4D,E), showing that 5$\mathrm{HT}_{1 \mathrm{~B}} \mathrm{R}$ I3 loop confers constitutive endocytosis capacity to $5-H_{1} T_{1 A}$ by promoting the adoption of active receptor conformation. We also tested $\left.{ }^{35} \mathrm{~S}\right] \mathrm{GTP} \gamma \mathrm{S}$ binding characteristics of membranes from LLC-PK1 expressing Aba chimera. $\left[{ }^{35}\right.$ S]GTP $\gamma S$ binding could be increased significantly by the agonist 5-CT, but methiothepin treatment did not decrease basal [ ${ }^{35}$ S]GTP $\gamma S$ binding for the chimera (Figure 4F). Apparently, the active 5- $\mathrm{HT}_{1 \mathrm{~A}} \mathrm{R}$ conformation, which is induced by the presence of the $5-\mathrm{HT}_{1 \mathrm{~B}} \mathrm{R} \mathrm{I3}$ loop and which is reversed by the inverse agonist methiothepin, is not fully identical to the G-protein mobilizing active conformation of $5-H_{1} T_{1 A} R$, typically produced through activation by $5-\mathrm{HT}_{1 \mathrm{~A}} \mathrm{R}$-specific agonists.

\section{The third intracellular loop of $5-H T_{1 B} R$ is responsible for constitutive-endocytosis-driven axonal targeting}

Next we investigated the role of the third intracellular loop of the $5-\mathrm{HT}_{1 \mathrm{~B}} \mathrm{R}$ in axonal targeting. For this, we evaluated surface distribution of the Flag-tagged Aba chimera in neurons. We found that the Flag-Aba chimera is mostly polarized to the axonal surface (Figure $5 \mathrm{~A}, \mathrm{~B}$ ), similar to $5-\mathrm{HT}_{1 \mathrm{~B}} \mathrm{R}$ (see Figure 1C,D), displaying an $A / D$ ratio of $1.5 \pm 0.1$ $(n=23)$ and a predominantly axonal surface distribution in $79.1 \pm 3.6 \%$ neurons (both results pooled from at least two independent experiments, not significantly different from $\left.5-H_{1 B} \mathrm{R}\right)$. Thus, the replacement of the third intracellular loop of $5-\mathrm{HT}_{1 \mathrm{~A}} \mathrm{R}$ with that of $5-\mathrm{HT}_{1 \mathrm{~B}} \mathrm{R}$ is sufficient to alter the surface repartition of the receptor from the somatodendritic compartment, typical of $5-\mathrm{HT}_{1 A} \mathrm{R}$ (Figure $1 \mathrm{~A}, \mathrm{~B}$ ), to the axon, characteristic of $5-\mathrm{HT}_{1 \mathrm{~B}} \mathrm{R}$ (Figure $\left.1 \mathrm{C}, \mathrm{D}\right)$. This suggests that the third intracellular loop is a critical region for axonal distribution of $5-\mathrm{HT}_{1 \mathrm{~B}} \mathrm{R}$. We verified this prediction by transfecting neurons with the Bab chimera, where the third intracellular loop of $5-\mathrm{HT}_{1 \mathrm{~B}} \mathrm{R}$ is replaced with that of $5-\mathrm{HT}_{1 \mathrm{~A}} \mathrm{R}$. Strikingly, the Bab chimera showed a mostly somatodendritic surface distribution, similar to the WT 5-HT ${ }_{1 A} \mathrm{R}$ (Figure S4C,D). Thus, the third intracellular loop of $5-\mathrm{HT}_{1 \mathrm{~B}} \mathrm{R}$ is both necessary and sufficient to target these constructs to the axonal surface, confirming and extending the previous observation (29).
As we have shown above, in non-neuronal cells, that replacement of the third intracellular loop of $5-\mathrm{HT}_{1 \mathrm{~A}} \mathrm{R}$ with that of $5-\mathrm{HT}_{1 \mathrm{~B}} \mathrm{R}$ confers spontaneous adoption of an active receptor conformation, which results in methiothepinsensitive constitutive endocytosis, we examined whether a similar mechanism is responsible for the axonal targeting of the Aba chimera in neurons. First, we found that Aba shows a high rate of constitutive endocytosis in neurons, not significantly different from $5-\mathrm{HT}_{1 \mathrm{~B}} \mathrm{R} \quad(70.0 \pm 1.9 \%$, Figure 5C,D). Next, we examined the targeting kinetics of newly synthesized Aba receptors, following BFA washout in the presence or absence of the inverse agonist methiothepin, which inhibits activation-dependent endocytosis of Aba receptors, as shown above. In the vehicle-treated controls, the Aba chimera followed the kinetics of $5-\mathrm{HT}_{1 \mathrm{~B}} \mathrm{R}$ targeting, by displaying first a predominantly somatodendritic and uniform distribution on the neuronal surface, which was transformed to a predominantly axonal distribution pattern starting at 4-8 h after BFA washout (Figure 5E,G,H). Strikingly, methiothepin treatment inhibited efficient axonal targeting of Aba receptors, leading to a predominantly uniform labeling at $24 \mathrm{~h}$ following BFA washout (Figure 5F,G,H). The significant effect of methiothepin on Aba targeting kinetics was confirmed by the trajectory observed on the PCA plot (Figure S5). Thus, an inverse agonist was able to rescue, at least partially, the distribution phenotype of the Aba chimera toward 5-HT ${ }_{1 \mathrm{~A}} \mathrm{R}$ phenotype, suggesting that grafting the third intracellular loop of $5-\mathrm{HT}_{1 \mathrm{~B}} \mathrm{R}$ to $5-\mathrm{HT}_{1 \mathrm{~A}} \mathrm{R}$ results in an elevated predisposition to constitutively adopt an active receptor conformation, which ultimately results in constitutive somatodendritic-endocytosis-driven axonal targeting.

\section{5-HT $T_{1 B} R$ localization is not affected by $p 11$ protein}

Because of the role of the third intracellular domain in constitutive endocytosis and axonal targeting of $5-\mathrm{HT}_{1 \mathrm{~B}} \mathrm{R}$, we wondered whether the p11 protein [also called S100A10, 42C, calpactin I light chain and annexin II light chain (40)], which was previously reported to interact with the third intracellular loop of $5-\mathrm{HT}_{1 \mathrm{~B}} \mathrm{R}$, to colocalize with $5-\mathrm{HT}_{1 \mathrm{~B}} \mathrm{R}$ at the plasma membrane in HeLa cells and to increase surface localization of co-transfected $5-\mathrm{HT}_{1 \mathrm{~B}} \mathrm{R}$ in COS-7 cells (41), could also play also a role in targeting $5-\mathrm{HT}_{1 \mathrm{~B}} \mathrm{Rs}$ to the axonal plasma membrane. We have co-transfected neurons with Flag-5- $\mathrm{HT}_{1 \mathrm{~B}} \mathrm{R}$ and $\mathrm{p} 11-\mathrm{eYFP}$ and measured the $A / D$ ratio of surface-localized $5-H_{1 B} R$. The result was not significantly different from the controls expressing eYFP instead of p11-eYFP (Figure 6).

Surprisingly, when we co-transfected HeLa and COS-7 cells with p11-eYFP and 5- $\mathrm{HT}_{1 \mathrm{~B}}-\mathrm{HcR}_{\mathrm{C}}$ ed, we did not find colocalization of the two proteins, because p11 was mostly localized at the plasma membrane while $5-\mathrm{HT}_{1 \mathrm{~B}}$ was localized mostly in cytoplasmic vesicle-like structures (Figure S6B), similar to the above-reported findings in LLCPK1 cells but in variance with the previously reported data (41). Furthermore, we measured the MFR of both proteins and we found that coexpression of $\mathrm{p} 11$ and $5-\mathrm{HT}_{1 \mathrm{~B}} \mathrm{R}$ did not alter the distribution of each protein in HeLa cells 


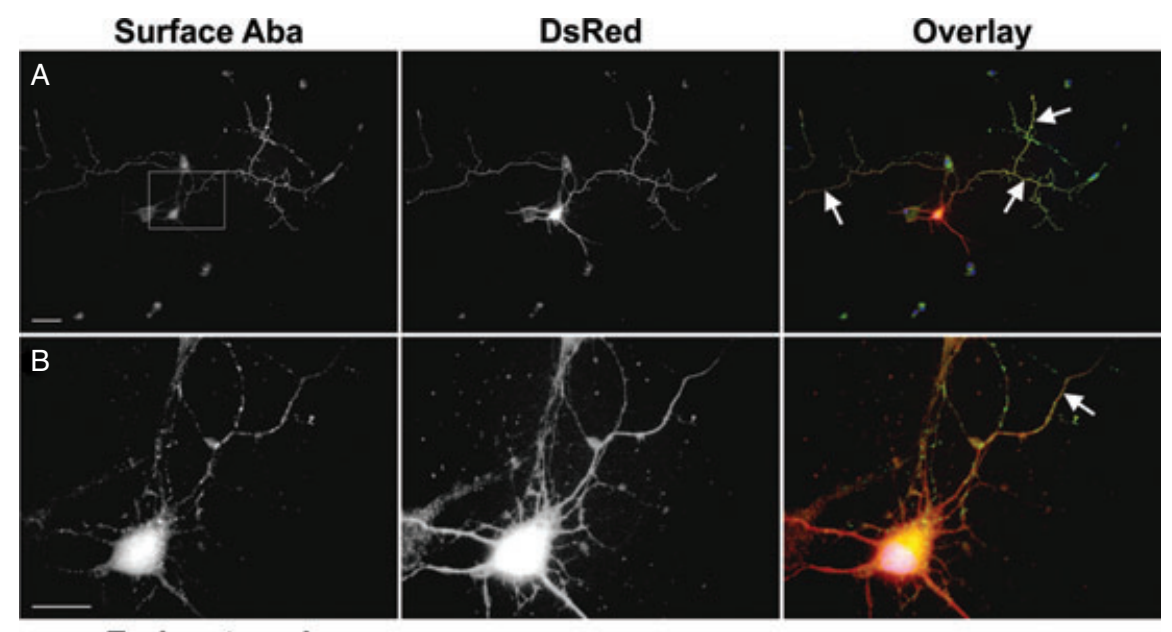

Endocytosed
+ Surface M2

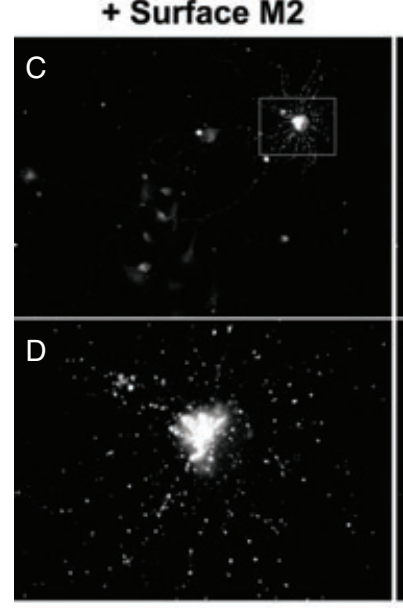

E

Vehicle
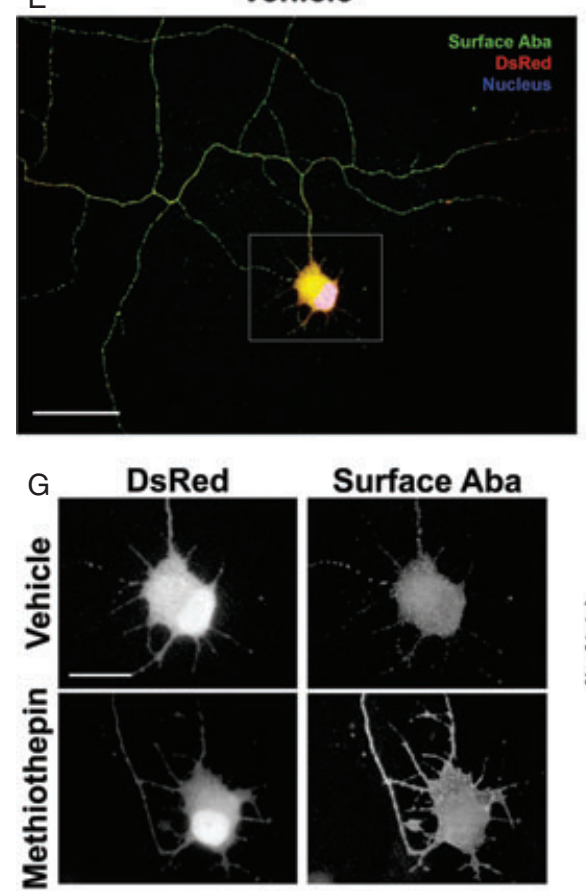

Surface M2

Overlay

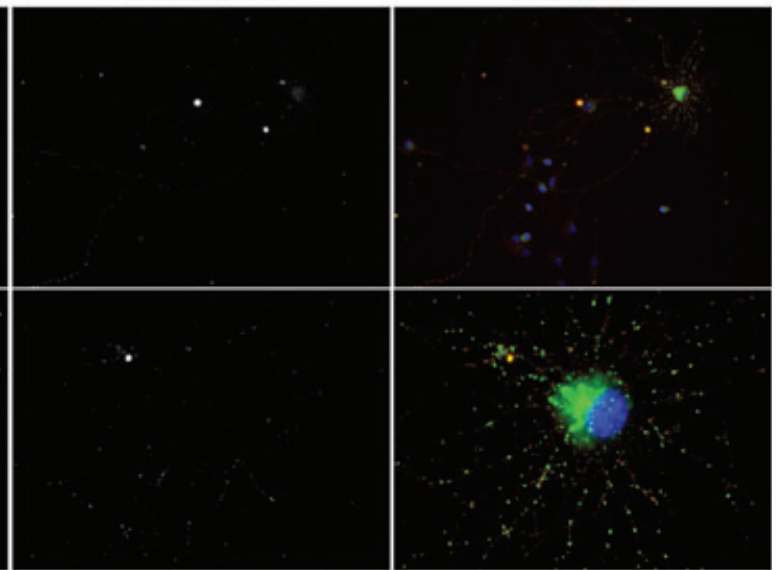

F Methiothepin $5 \mu \mathrm{M}$

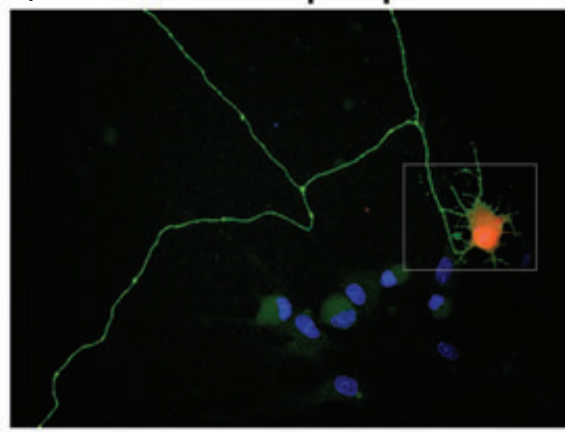

$\mathrm{H}$

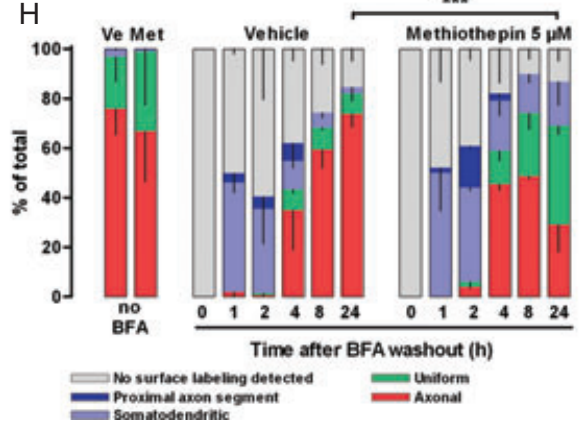

Figure 5: Legend on next page.

Traffic 2011; 12: 1501-1520 
and actually decreased their membrane localization in COS-7 cells (Figure S6). Accordingly, in our experimental conditions, we could not detect significant colocalization of p11 and $5-H_{1} T_{1 B} R$, and coexpression of p11 does not seem to enhance the targeting of $5-\mathrm{HT}_{1 \mathrm{~B}} \mathrm{R}$ to the membrane of HeLa and COS-7 cells or to the axonal surface in neurons.

\section{The complete sequence of the third intracellular loop of $5-H T_{1 B} R$ is necessary for efficient constitutive-endocytosis-driven axonal targeting}

To determine whether we could delimit a region responsible for constitutive endocytosis and axonal targeting inside the 5- $\mathrm{HT}_{1 \mathrm{~B}} \mathrm{R} / 3$ loop, we compared the aminoacid sequence of the $5-H_{1} T_{1 A} R$ and $5-H T_{1 B} R \quad 13$ loops (Figure 7A). The alignment of the two sequences indicated that the $5-\mathrm{HT}_{1 \mathrm{~B}} \mathrm{R} / 3$ loop can be divided into two regions (I3b1 and $\mid 3 \mathrm{~b} 2$ ) and the $5-\mathrm{HT}_{1 \mathrm{~A}} \mathrm{R} \mid 3$ loop into three regions (I3a1, I3a2 and $13 \mathrm{a} 3$ ). A relatively high homology is found between $13 \mathrm{~b} 1$ and $13 \mathrm{a} 1$ and between $13 \mathrm{~b} 2$ and I3a3 (38 and 42\% identity, respectively, comparable with the overall $43 \%$ identity between $5-\mathrm{TH}_{1 A} \mathrm{R}$ and $\left.5-\mathrm{HT}_{1 \mathrm{~B}} \mathrm{R}\right)$, while the 44-amino-acid middle region of the $5-\mathrm{HT}_{1 \mathrm{~A}} \mathrm{R}$ 13 loop (I3a2) is absent from the $5-H_{1} T_{1 B} R$ I3 loop. On the basis of these comparisons, we designed chimeric 13 loops containing a combination of the homologous regions (I3ab and I3ba loops, Figure 7B) to study the specific role of the two regions of the $5-\mathrm{HT}_{1 \mathrm{~B}} \mathrm{R} / 3$ loop in endocytosis and targeting. In addition, to analyze the role of the middle region of the $5-H_{1 A} \mathrm{R} / 3$ loop, we deleted this region from the $5-\mathrm{HT}_{1 \mathrm{~A}} \mathrm{R} / 3$ loop or inserted it in the $5-\mathrm{HT}_{1 \mathrm{~B}} \mathrm{I3}$ loop (I3aa and I3bab loops, respectively, Figure 7B). The four chimeric loops were grafted to replace the 13 loop on the $5-\mathrm{HT}_{1 \mathrm{~A}}$ and $5-\mathrm{HT}_{1 \mathrm{~B}}$ receptor backbones, the obtained constructs were transfected in neurons, and the distribution of the resulting sub-13 chimeras at the neuronal surface was measured (Figure 7D). PCA and K-means analysis were then performed to compare the distribution of these constructs with that of $5-H T_{1 A} R, 5-H T_{1 B} R$, as well as Aba, Baa, $\mathrm{Bab}$ and Bba chimeras (Figure S4D). First, we observed that all tested constructs segregated in three well-defined clusters (Figure 7E, inset, as confirmed by silhouette value analysis). As expected, the receptors and chimeras previously described as mainly somatodendritic $\left(5-\mathrm{HT}_{1 \mathrm{~A}} \mathrm{R}\right.$ and $\mathrm{Bab}$ ) or mainly axonal $\left(5-\mathrm{HT}_{1 \mathrm{~B}} \mathrm{R}\right.$ and $\left.\mathrm{Aba}\right)$ segregated in the two most distant clusters. However, more interestingly, the constructs belonging to each cluster could be defined by the composition of their 13 loop: all constructs containing the $\mathrm{N}$-terminal and $\mathrm{C}$-terminal regions of the $5-\mathrm{HT}_{1 \mathrm{~A}} \mathrm{R}$ 13 loop, including those containing the I3aa chimeric loop, were found in the 'somatodendritic' cluster; all constructs containing the full $5-\mathrm{HT}_{1 \mathrm{~B}} \mathrm{R} / 3$ loop, including those containing the I3bab chimeric loop, were found in the 'axonal' cluster; and the constructs containing a combination of the homologous regions of the $5-\mathrm{HT}_{1 \mathrm{~A}} \mathrm{R}$ and $5-\mathrm{HT}_{1 \mathrm{~B}} \mathrm{R} / 3$ loop were found in the third cluster, characterized by an intermediate distribution between the two other clusters. Overall, this repartition suggests that both regions of the $5-\mathrm{HT}_{1 \mathrm{~B}} \mathrm{R} / 3$ loop are implicated in axonal targeting and that the entire 13 loop is necessary for an efficient axonal targeting. Conversely, somatodendritic localization of $5-H_{1 A} R$ does not seem to be defined by a single targeting motif.

These results have further confirmed the notion that 13-mediated axonal targeting of $5-\mathrm{HT}_{1 \mathrm{~B}} \mathrm{R}$ is not regulated by a single targeting motif but rather by an overall effect on receptor conformation, translated through the level of spontaneous endocytosis. To verify the validity of this model, we measured the constitutive endocytosis of each 13 loop chimera (Figure 7F) and observed intermediate values between the values obtained for $5-\mathrm{HT}_{1 \mathrm{~A}}$ and $5-\mathrm{HT}_{1 \mathrm{~B}}$ receptors. We then used these data to investigate whether there is a strong correlation

Figure 5: Aba chimera is targeted to the surface of axons in a similar way as $\mathbf{5}-\mathbf{H T}_{\mathbf{1 B}}$ receptor. A and B) Flag-Aba chimera was co-transfected with soluble DsRed (red), and surface-localized chimeras (green) were detected in live cells with M2 anti-FLAG antibody. The chimera is mainly localized at the axonal surface of neurons (arrows). C and D) DIV8 neurons expressing Flag-Aba chimera were fed for $1 \mathrm{~h}$ at $37^{\circ} \mathrm{C}$ with anti-Flag M2 antibody pre-coupled with goat anti-mouse antibody (green) and incubated for $1 \mathrm{~h}$ at $4^{\circ} \mathrm{C}$ with anti-goat antibody (red). After fixation, green labeling shows that Flag-Aba ( $\mathrm{C}$ and $\mathrm{D}$ panels) is constitutively endocytosed in the somatodendritic compartment. E-H) Time-course of Aba chimera insertion into the neuronal plasma membrane. DIV7 neurons were co-transfected with Flag-Aba and DsRed for a 3-h incubation in transfection medium. They were then incubated overnight with $0.75 \mu \mathrm{g} / \mathrm{mL}$ BFA to block protein export from the Golgi apparatus. After extensive washes (BFA washout), neurons were incubated in either regular medium or in the presence of $5 \mu \mathrm{M}$ inverse agonist methiothepin for $0,1,2,4,8$ and $24 \mathrm{~h}$. At these time-points, neurons were labeled for surface Flag-Aba chimera and fixed. The proportion of each category was determined for each condition and time-point as described in the experimental procedures. E, G top) Flag-Aba labeling $24 \mathrm{~h}$ after BFA washout in control condition. Flag-Aba is correctly localized at the surface of axons. F, G bottom) Flag-Aba labeling $24 \mathrm{~h}$ after BFA washout in the presence of $5 \mu \mathrm{M}$ methiothepin. Flag-Aba is present as a uniform surface labeling. H) Time-course of Flag-Aba surface targeting in control and treated conditions. Right after BFA washout (0 h), no Flag-Aba labeling is present at the neuronal plasma membrane. Then, for both treatment conditions, Flag-Aba chimeras transiently appear on the somatodendritic and proximal axon segment surface (at 1 and $2 \mathrm{~h}$ ). This precedes establishment of the proper axonal distribution (after $24 \mathrm{~h}$, illustrated in $\mathrm{E}$ and $\mathrm{G}$ top) for untreated neurons, whereas inverse-agonist treatment inhibited the emergence of the axonal surface distribution of Flag-Aba (majority of 'uniform' phenotype $24 \mathrm{~h}$ after BFA washout in the presence of methiothepin, illustrated in F and $G$ bottom). In the absence of incubation with BFA (two bars on the left), treatment with methiothepin for $8 \mathrm{~h}$ does not alter the distribution of Flag-Aba in comparison with vehicle treatment. Results are mean \pm SEM per category and represent data from two pooled independent experiments ( $n=70-135$ neurons per condition). The $p$-value for the significance of the difference between couples of surface distributions was computed using Pearson's $\chi^{2}$ homogeneity test. On overlay images, blue represents nuclei. ${ }^{* *} \mathrm{p}<0.001$. A, C, E, F, scale bar: $50 \mu \mathrm{m}$; b, d, g, scale bar: $20 \mu \mathrm{m}$. 
Carrel et al.

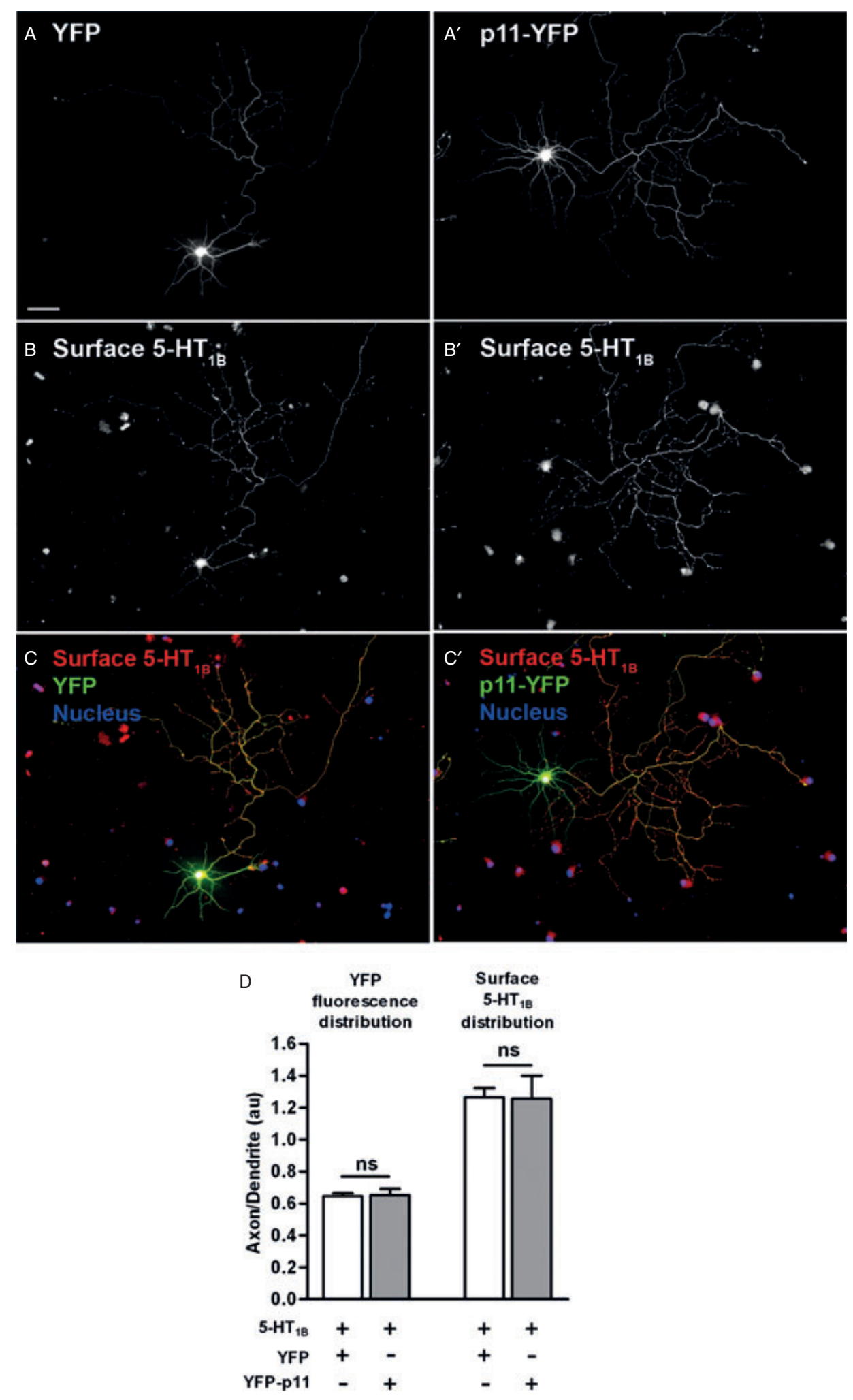

Figure 6: $\mathbf{p} 11$ overexpression does not modify plasma membrane targeting of $5-\mathrm{HT}_{1 \mathrm{~B}} \mathrm{R}$ receptors in hippocampal neurons. DIV8 neurons were co-transfected with Flag-5- $\mathrm{HT}_{1 \mathrm{~B}}$ and soluble eYFP (A) or p11-eYFP protein $\left(\mathrm{A}^{\prime}\right)$ and labeled for the surface 5- $\mathrm{HT}_{1 \mathrm{~B}} \mathrm{R}$ population $\left(B, B^{\prime}, C, C^{\prime}\right)$. D) Quantification of the $A / D$ ratio for the surface labeling of $5-H T_{1 B} R$. Results were not significantly different whether neurons were transfected with eYFP or p11-eYFP. Each bar is the mean \pm SEM from 30 to 50 neurons (in two pooled independent experiments). ns, non-significant. Scale bar: $50 \mu \mathrm{m}$. 
I31A RIRK TVRKVEKKGAGTSLGTSSAPPPKKSLNGQPGSGDWRRCAENRAVGTPCTNGAVRQGDDEATLEVIEVHRVGNSKEHLP LPSESGSNSYAPACLERKNERNAEAKRKMALARERKTVKTI $* * * * *^{*} . *::: .^{*} *{ }^{*} * \ldots *$

I31B RILKQTPNKTGKRLTRAQLITDS PGSTSS

VTSTNSRYPEVPSESGSPVYVNOVKVRVSDALIE KKKLMAARERKATKT

I3b1

I3b2

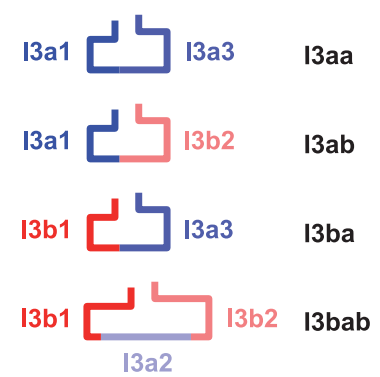

C
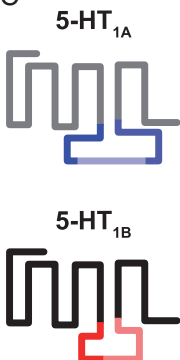

$5-\mathrm{HT}_{1 \mathrm{~A}}$ I3aa

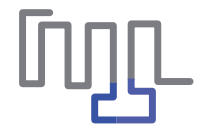

$5-\mathrm{HT}_{1 \mathrm{~B}}$ I3aa

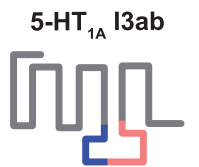

$5-\mathrm{HT}_{1 \mathrm{~B}} 13 \mathrm{ab}$
$5-\mathrm{HT}_{1 \mathrm{~A}} 13 \mathrm{ba}$

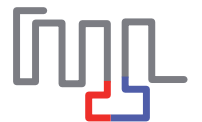

5-HT 1 I3ba

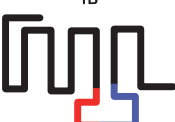

$5-\mathrm{HT}_{1 \mathrm{~A}}$ I3bab

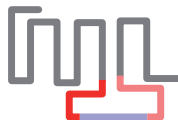

$5-\mathrm{HT}_{1 \mathrm{~B}}$ I3bab

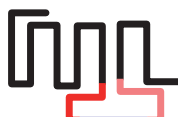

D

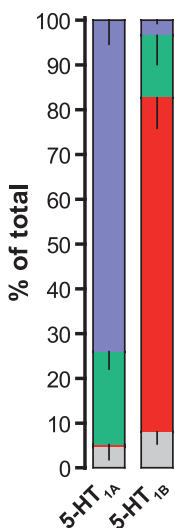

E

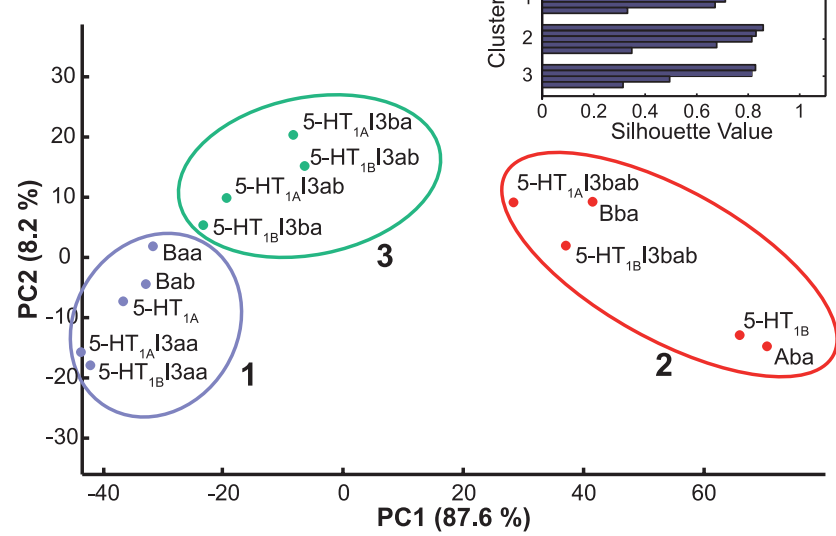

Somatodendritic Uniform
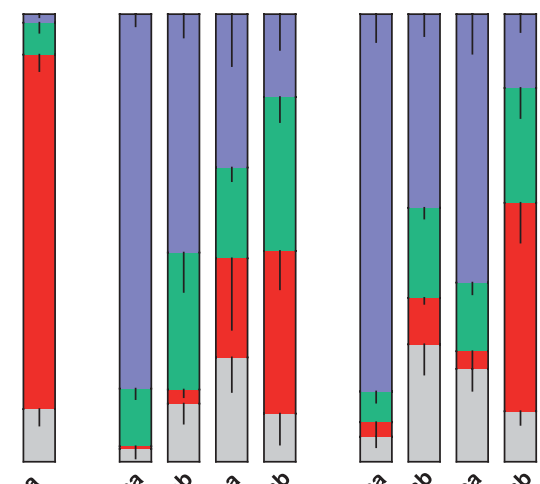

$3^{20} 3^{20} 3^{0^{2}} 3^{200}$

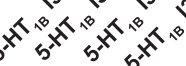

F

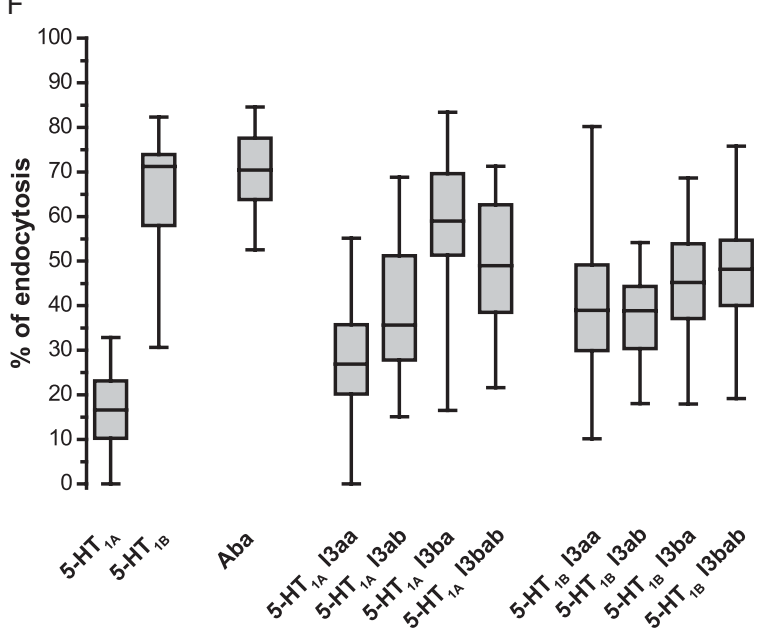

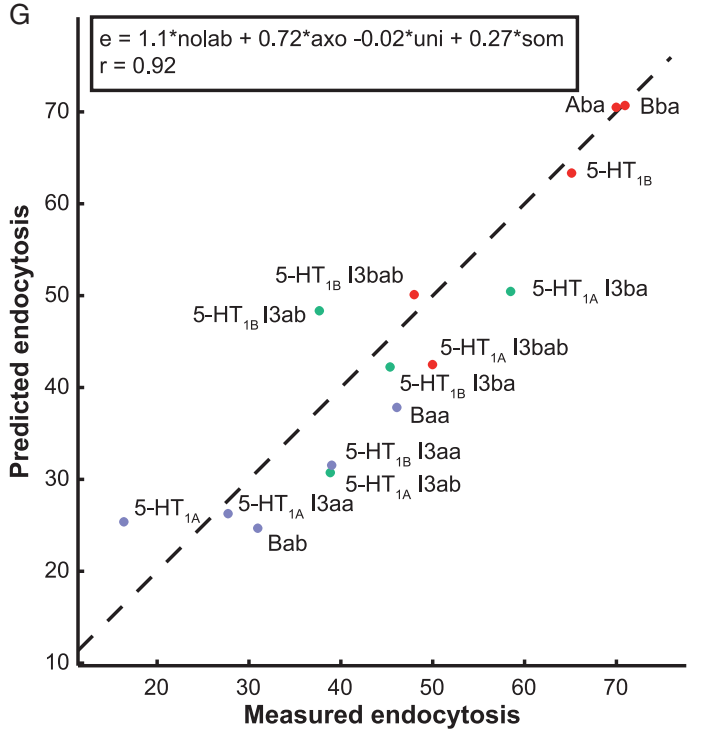

Figure 7: Legend on next page. 


\section{Carrel et al.}

between the level of constitutive endocytosis and neuronal distribution of all tested receptors and chimeras. A regression approach allowed us to find a high linear correlation between endocytosis and neuronal distribution ( $r=0.92$, Figure 7G), confirming our model of conformation-dependant constitutive-endocytosis-driven axonal targeting.

\section{Discussion}

Here, we have investigated the mechanism responsible for the localization of $5-\mathrm{HT}_{1 \mathrm{~B}} \mathrm{R}$ on the axonal surface and our results clearly show that active-conformationdependent constitutive somatodendritic endocytosis is a key mechanism for this process. Blockade of endocytosis either by co-transfection with dominant-negative mutants of endocytic proteins or by treatment with an inverse agonist yielded a non-polarized distribution of newly synthesized $5-H T_{1 B} R$. Comparison of endocytosis of various 5- $\mathrm{HT}_{1 \mathrm{~A}}$ and $5-\mathrm{HT}_{1 \mathrm{~B}}$ chimeras showed that the presence of the complete third intracellular loop of $5-\mathrm{HT}_{1 \mathrm{~B}} \mathrm{R}$ is necessary and sufficient for this active-conformation-dependent constitutive endocytosis. Thus, in neurons, replacement of the third intracellular loop of $5-\mathrm{HT}_{1 \mathrm{~A}} \mathrm{R}$ by that of the $5-\mathrm{HT}_{1 \mathrm{~B}} \mathrm{R}$ (Aba chimera) is sufficient to change the distribution of $5-\mathrm{HT}_{1 A} \mathrm{R}$ from somatodendritic to axonal. We were able to partially restore the $5-\mathrm{HT}_{1 \mathrm{~A}} \mathrm{R}$ phenotype by treating neurons expressing the newly synthesized Aba chimera with the inverse agonist methiothepin, showing the importance of the active receptor conformation state in the axonal targeting process.

\section{Differential targeting of $5-H T_{1 A}$ and $5-H T_{1 B}$ receptors} $5-\mathrm{HT}_{1 \mathrm{~A}} \mathrm{R}$ and $5-\mathrm{HT}_{1 \mathrm{~B}} \mathrm{R}$ are two GPCRs that exhibit high homology in their amino-acid sequences and share many common features (21), but their distribution throughout the rat central nervous system (CNS) shows major differences, in line with their respective functions: the $5-\mathrm{HT}_{1 \mathrm{~A}} \mathrm{R}$ is localized on the somas and dendrites of neurons where it modulates nerve impulse flow $(22,25,27)$, whereas the $5-\mathrm{HT}_{1 \mathrm{~B}} \mathrm{R}$ is found in preterminal unmyelinated axons where it participates in a local control of the release of serotonin or other neurotransmitters $(26,27)$. Previously, we identified amino-acid sequence domains important for the respective localization of $5-H T_{1 A} R$ and $5-\mathrm{HT}_{1 \mathrm{~B}} \mathrm{R}$ in epithelial cells and in neurons and showed that the short cytosolic C-terminal tail of both receptors plays a crucial role in their initial plasma membrane targeting and that the third intracellular loop was important for the axonal targeting of the $5-\mathrm{HT}_{1 \mathrm{~B}} \mathrm{R}(28,29,34,42)$.

Here, we showed that both $5-\mathrm{HT}_{1 \mathrm{~A}} \mathrm{R}$ and $5-\mathrm{HT}_{1 \mathrm{~B}} \mathrm{R}$ exhibit constitutive G-protein activation although to a different degree. The $18 \%$ basal activation of the $5-\mathrm{HT}_{1 \mathrm{~A}} \mathrm{R}$ is in agreement with that already reported for both the native receptor in rat hippocampal membranes (43) and the receptor expressed in transfected cell lines (44). For the rat $5-\mathrm{HT}_{1 \mathrm{~B}} \mathrm{R}$, the inverse agonist SB224289 inhibits the basal $\left[{ }^{35} \mathrm{~S}\right] \mathrm{GTP} \gamma \mathrm{S}$ binding to a larger extent, indicating a constitutive activation reaching $40 \%$, in the same range as that found previously for human $5-\mathrm{HT}_{1 \mathrm{~B}} \mathrm{R}$ stably expressed in transfected $\mathrm{CHO}$ cells $(37,38)$. This constitutive activation was well correlated with $5-\mathrm{HT}_{1 \mathrm{~B}} \mathrm{R}$ endocytosis in cell lines and was a result of spontaneous adoption of activated receptor conformation since the inverse agonist blocked it, as previously shown for several other constitutively active GPCRs (12-17).

\section{Somatodendritic endocytosis}

The differences between 5- $\mathrm{HT}_{1 \mathrm{~A}} \mathrm{R}$ and $5-\mathrm{HT}_{1 \mathrm{~B}} \mathrm{R}$ localization in neurons appeared to be correlated with their level of constitutive somatodendritic endocytosis. The 5- $\mathrm{HT}_{1 \mathrm{~A}} \mathrm{R}$ is confined to the somatodendritic plasma membrane without significant spontaneous endocytosis in this compartment, whereas the $5-\mathrm{HT}_{1 \mathrm{~B}} \mathrm{R}$ is endocytosed in soma and dendrites, and accumulates on the axonal plasma membrane (Figure 1). Comparison between these two closely related receptors that display a differential localization and a markedly different constitutive somatodendritic endocytosis emphasizes the role of constitutive endocytosis for the axonal localization, as previously described for NgCAM (6) and the CB1 cannabinoid receptor $(11,18)$. Indeed, the kinetics of $5-\mathrm{HT}_{1 \mathrm{~B}} \mathrm{R}$ membrane insertion, following a BFA blockade, showed that the receptor was first delivered to the somatodendritic compartment before

\footnotetext{
Figure 7: Sub-l3 chimeras indicate lack of dominant targeting motifs and show that the complete $\mathbf{I}_{3}$ loop of $5-\mathrm{HT}_{1 \mathrm{~B}} \mathrm{R}$ is necessary and sufficient for efficient axonal targeting. A) Alignment of the amino-acid sequences of the rat $5-H T_{1 A} R$ and $5-H T_{1 B} R I 3$ loops highlighting the homologous regions (I3a1 with $13 \mathrm{~b} 1$ and $13 \mathrm{a} 3$ with $13 \mathrm{~b} 2$ ) and the specific middle region of the $5-\mathrm{HT}_{1 \mathrm{~A}} \mathrm{R} / 3 \mathrm{loop}$ (I3a2). * indicates a position with identical residues, : and. indicates positions with conservation of a 'strong' and 'weak' homology group, respectively, according to CLUSTAL W Alignment program (69). B) Schematic representation of the chimeric loops combining the regions determined in A. C) Schematic representation of 5-HT $\mathrm{H}_{1 \mathrm{~A}} \mathrm{R}$ - and $5-\mathrm{HT}_{1 \mathrm{~B}} \mathrm{R}$-based constructs containing the chimeric I3 loops. D) Quantification of surface distribution of Flag-tagged versions of the constructs described in C after $24 \mathrm{~h}$ of expression in DIV7-transfected neurons (distribution of Flag-5- $\mathrm{HT}_{1 \mathrm{~A}}$ and Flag-5- $\mathrm{HT}$ 1B receptors as well as Flag-Aba are reminded from Figures 1 and S4). E) PCA plot of the distribution of Flag-5- $\mathrm{HT}_{1 \mathrm{~A}}$, Flag-5HT $1 \mathrm{~B}$ receptors and of the 12 chimeras used in the study, showing the clusters generated by $K$-means for $K=3$. Inset: Silhouette plot showing the compactness of each individual cluster. The horizontal axis represents the silhouette value of each individual receptor. Their large positive values show that each receptor points toward its own cluster, and not to a neighbor cluster. F) Quantification of endocytosis of Flag-tagged versions of the constructs described in $\mathrm{C}$ (endocytosis of Flag-5- $\mathrm{HT}_{1 \mathrm{~A}}$ and Flag-5- $\mathrm{HT}_{1 \mathrm{~B}}$ receptors as well as Flag-Aba are reminded from Figure S4). G) Graph plotting the observed constitutive endocytosis rate of $5-\mathrm{HT}_{1 \mathrm{~A}} \mathrm{R}, 5 \mathrm{HT}_{1 \mathrm{~B}} \mathrm{R}$ and the 12 chimeras used in the study versus their predicted constitutive endocytosis rate as determined by linear regression.
} 
being targeted to the axonal membrane. Such kinetic characteristics are compatible with a transcytotic model implicating specific somatodendritic endosomes that can serve to redistribute a distinct set of membrane proteins from dendrites to axons (7).

\section{Key role of the third intracellular loop of $5-H T_{1 B} R$ in receptor endocytosis}

The Aba chimera, obtained by replacement of the third intracellular loop of $5-\mathrm{HT}_{1 \mathrm{~A}} \mathrm{R}$ with that of $5-\mathrm{HT}_{1 \mathrm{~B}} \mathrm{R}$, is efficiently targeted to the axonal plasma membrane, confirming the role of this specific domain in axonal localization (29). Our present results elucidate the mechanism of this targeting by showing that 13 is responsible for the constitutive-activation-driven endocytosis which drives axonal targeting of $5-\mathrm{HT}_{1 \mathrm{~B}} \mathrm{R}$. At steady state, most GPCRs are held in the basal, relatively inactive conformational state by non-covalent intramolecular interactions (9). Two such interactions, the 'rotamer toggle switch' and the 'ionic lock', both between the third and sixth transmembrane helices, are critical to stabilize the inactive state of model GPCRs. Correspondingly, the 13 loop, which is contiguous with the cytoplasmic extremity of the sixth transmembrane helix, plays an important role in the regulation of the conformational state as well as the endocytosis of several GPCRs (45-49). Mutations in the C-terminal region of the 13 loop of several GPCRs can lead to increased constitutive activity, therefore indicating that the 13 loop contains elements stabilizing the inactive form (46). Our results suggest that in the Aba chimera, replacement of the third intracellular loop of $5-\mathrm{HT}_{1 A} \mathrm{R}$ with that of $5-\mathrm{HT}_{1 \mathrm{~B}} \mathrm{R}$ confers spontaneous adoption of an active conformation, which is reversible by the binding of the inverse agonist methiothepin. Results derived from sitedirected mutagenesis studies and from three-dimensional models based on the high-resolution structure of bacteriorhodopsin indicate that methiothepin binds to a pocket formed by the transmembrane regions to induce conformational changes within the transmembrane bundle $(50,51)$. Consequently, methiothepin-mediated rescue of the Aba phenotype further advocates that the primary effect of grafting the 13 of $5-\mathrm{HT}_{1 \mathrm{~B}} \mathrm{R}$ on $5-\mathrm{HT}_{1 \mathrm{~A}} \mathrm{R}$ is a conformational shift toward a more active receptor state. Conversely, grafting the 13 of $5-H_{1} \mathrm{~T}$ into the 5- $\mathrm{HT}_{1 \mathrm{~B}} \mathrm{R}$ (Bab chimera) abolishes constitutive internalization of $5-H T_{1 B} R$, showing that the 13 of $5-H T_{1 B} R$ is both necessary and sufficient to induce spontaneous receptor activation. Interestingly, while the cytoplasmic surface of the Aba chimera is recognized as activated by the endocytic machinery of both LLC-PK1 cells and hippocampal neurons leading to efficient endocytosis and axonal targeting, the same cytoplasmic surface is not efficacious to spontaneously mobilize appropriate G-proteins, further confirming the notion that GPCR activation occurs through different conformational intermediates, which may be differently connected to downstream effectors (9,52-54). Indeed, it was reported that the constitutive activity generated by modification of the 13 loop can trigger different signaling pathways than those activated by agonist stimulation $(45,55)$. Another possibility is that G-protein activation implicates the simultaneous presence of additional intracellular regions of the activated receptors, such as the 11 and 12 loops or the $\mathrm{C}$ terminus.

Actually we do not know if the 13 of $5-\mathrm{HT}_{1 \mathrm{~B}} \mathrm{R}$ requires protein partners to increase the portion of the receptor in the active conformation state. Several proteins interacting with GPCR 13 loops have been identified and some of them have been implicated in receptor surface expression or internalization $(56,57)$. In particular, the protein p11 was recently reported to interact with the 13 loop of $5-H T_{1 B} R$, and was proposed to be implicated in $5-\mathrm{HT}_{1 \mathrm{~B}} \mathrm{R}$ targeting to the plasma membrane, based on the apparent colocalization with $5-\mathrm{HT}_{1 \mathrm{~B}} \mathrm{R}$ at the plasma membrane in HeLa cells (41). Expression of p11 was also suggested to increase surface localization of the coexpressed receptor in COS-7 cells (41). This suggestion was based on the intuitive assumption that in the absence of activating ligands, $5-\mathrm{HT}_{1 \mathrm{~B}} \mathrm{Rs}$ should be localized to the plasma membrane. However, our data (Figures 6 and S6), by showing different subcellular distributions for $5-\mathrm{HT}_{1 \mathrm{~B}} \mathrm{R}$ and $\mathrm{p} 11$ both in HeLa and COS-7 cells and a lack of plasma membrane targeting effect for $5-\mathrm{HT}_{1 \mathrm{~B}} \mathrm{R}$ by co-transfected $\mathrm{p} 11$, do not support such a role for p11 in $5-\mathrm{HT}_{1 \mathrm{~B}} \mathrm{R}$ targeting in neurons, nor in non-polarized cells. Indeed, while p11 is mostly localized to the plasma membrane in different cell types (our present data and Ref. 58), the $5-\mathrm{HT}_{1 \mathrm{~B}} \mathrm{R}$, because of its spontaneous constitutive activity, displays a predominantly endosomal distribution in LLC-PK1, HeLa and COS-7 cells (our present data) as well as in HEK-293 cells (unpublished data). Therefore, if a partner of $5-\mathrm{HT}_{1 \mathrm{~B}} \mathrm{R}$ is responsible for its constitutive internalization and targeting, such protein likely remains to be discovered. However, our results obtained by the sub-13 chimeras do not suggest the presence of a single dominant axonal addressing motif, which could be a putative targeting-protein binding site.

In conclusion, we propose that the mechanism underlying differential targeting of $5-\mathrm{HT}_{1 \mathrm{~A}} \mathrm{R}$ and $5-\mathrm{HT}_{1 \mathrm{~B}} \mathrm{R}$ in neurons is related to differences in steady-state receptor conformational state, an important determinant of steady-state somatodendritic endocytosis. The third intracellular loop as well as pharmacological ligands are critical regulators of type-1 serotonin receptor conformation. Accordingly, it is likely that long-term neuropharmacological treatment may also result in redistribution of these receptors in neurons. It would be interesting to investigate the possible contribution of such treatment-induced receptor redistribution to both wanted and unwanted effects of therapeutic drugs acting through 5-HT-related mechanisms.

\section{Materials and Methods}

\section{Chemicals and antibodies}

Radioactive ligands $\left[{ }^{3} \mathrm{H}\right]$ Lysergic acid diethylamide $\left(\left[{ }^{3} \mathrm{H}\right] \mathrm{LSD}, 79.2\right.$ $\mathrm{Ci} / \mathrm{mmol})$ and (-)-3-[125 I]lodocyanopindolol (125/-CYP, $2000 \mathrm{Ci} / \mathrm{mmol})$ were from Amersham Bioscience. 5-carboxamido-tryptamine maleate 


\section{Carrel et al.}

(5-CT) and Isoproterenol were from Sigma. Naratriptan and 2'-methyl4'-(5-methyl-[1,2,4]oxadiazol-3-yl)-biphenyl-4-carboxylic acid [4-methoxy-3(4-methylpiperazine-1-yl) phenyllamide (GR127935) were from Glaxo. Pargyline hydrochloride was from Fluka Biochemika. SB224289 was from Tocris Bioscience. BFA was from Invitrogen. $M \beta C D$, cycloheximide and methiothepin were from Sigma. Mouse monoclonal anti-Flag M2 antibody was from Sigma. CY3-conjugated goat anti-mouse immunoglobulin $\mathrm{G}$ (lgG) were from Jackson Immuno Research. Alexa-Fluor ${ }^{\circledR}$ 488-conjugated goat anti-mouse IgG and Alexa-Fluor ${ }^{\circledR} 568$-conjugated donkey anti-goat were from Molecular Probes. Rabbit anti-MAP-2 antibody was from Chemicon.

\section{DNA constructs}

The complete coding sequences of rat $5-\mathrm{HT}_{1 \mathrm{~A}} \mathrm{R}(59)$ and rat $5-\mathrm{HT} \mathrm{T}_{1 \mathrm{~B}} \mathrm{R}(60)$ were subcloned into peGFP-N1 or pHcRedl expression vectors (Clontech) to obtain constructs tagged with eGFP or HcRed at their C-termini. Soluble DsRed plasmid was obtained by replacing the complete coding sequence of eGFP of the peGFP-N1 vector by the coding sequence of DsRed.

To obtain C-terminally eGFP-tagged chimera of $5-\mathrm{HT}_{1 \mathrm{~A}} \mathrm{R}$ and $5-\mathrm{HT}_{1 \mathrm{~B}} \mathrm{R}$, the sequences of the receptors in peGFP-N1 vector were divided into three compatible cassettes by the silent introduction of unique $E c o R I$ and $A c / l$ restriction sites using the QuikChange mutagenesis system (Agilent), at the beginning and at the end of the sequence encoding the third intracellular (I3) loop, respectively (Figure S4A). Flag-5- $\mathrm{HT}_{1 \mathrm{~A}}$ and Flag-5- $\mathrm{HT}_{1 \mathrm{~B}}$ constructs were described previously (34), as well as WT and mutant eps15-eCFP and dynamin-2-eCFP plasmids (11). Flag-Aba, Flag-Bab, Flag-Baa and Flag-Bba constructs were obtained by subcloning the complete coding sequence of according eGFP-tagged chimera into pFlag-CMV-6c expression vector (Sigma). The sequences coding the four chimeric 13 loops (Table S1) were synthesized by GenScript. N-terminally Flag-tagged I3 loop chimeras were then obtained by replacing the 13 loop of Flag-Aba and Flag-Bab by these sequences using EcoRI and Acll restriction sites. All constructs were verified by full-length sequencing. eYFP-p11 construct was a kind gift from Dr Ursula Rescher (Institute for Medical Biochemistry, Münster, Germany).

\section{Cell cultures}

LLC-PK1 cells, HeLa cells (ATCC CCL-2) and COS-7 cells (ATCC CRL-1651) were grown in DMEM (Invitrogen) supplemented with $4.5 \mathrm{~g} / \mathrm{L}$ glucose, GlutaMAX I (Invitrogen), 10\% fetal bovine serum, $10 \mathrm{U} / \mathrm{mL}$ penicillin $\mathrm{G}$ and $10 \mathrm{mg} / \mathrm{mL}$ streptomycin.

Neuronal cultures were made as described previously (11). Hippocampi of rat embryos were dissected at embryonic days 17-18. After trypsinization, tissue dissociation was achieved with a Pasteur pipette. Cells were counted and plated on poly-L-lysine-coated 15-mm-diameter coverslips, at a density of $60000-75000$ cells per $15-\mathrm{mm}$ dish (300-375 cells per square millimeter), in complete Neurobasal medium supplemented with B27 (Invitrogen), containing $0.5 \mathrm{~mm}$ L-glutamine, $10 \mathrm{U} / \mathrm{mL}$ penicillin $\mathrm{G}$ and $10 \mathrm{mg} / \mathrm{mL}$ streptomycin. Four to five hours after plating, the coverslips were transferred to a $90-\mathrm{mm}$ dish containing conditioned medium obtained by incubating glial cultures (70-80\% confluency) for $24 \mathrm{~h}$ in the complete medium described above. Experiments were performed in agreement with the institutional guidelines for use of animals and their care, in compliance with national and international laws and policies (Council directives no. 87-848, 19 October 1987, Ministère de l'Agriculture et de la Forêt, Service Vétérinaire de la Santé et de la Protection Animale, permission no. 75-974 to M. D.).

\section{Cell transfections}

LLC-PK1 cells were transfected by electroporation using Gene Pulser Xcell electroporation system (Biorad; $135 \mathrm{~V}, 1800 \mu \mathrm{F}$ in $200 \mu \mathrm{L}$ of DMEM containing 5 to $10 \times 10^{6}$ cells and $5-10 \mu \mathrm{g}$ plasmid DNA; relaxation time: $\sim 40$ milliseconds). Clones expressing the neomycin resistance marker were selected in G418 (1.25 mg/mL)-containing medium (61). After two passages, G4l8-resistant colonies were screened by observation of GFP fluorescence, and stably transfected clones were maintained in $0.4 \mathrm{mg} / \mathrm{mL}$ G418. Native 5-HT $1 \mathrm{~A}$ and $5-\mathrm{HT}_{1 \mathrm{~B}}$ receptor-stable LLC-PK1 clones were obtained previously in the laboratory (28).

HeLa and COS-7 cells were transfected in six-well plates with $1.2 \mu \mathrm{g}$ of plasmid DNA using Effectene reagent (Qiagen).

Hippocampal neurons were transfected on the 7th-8th day in vitro (DIV7-8) as follows: for each coverslip, plasmid DNA $(2 \mu \mathrm{g})$ and Lipofectamine 2000 $(1.25 \mu \mathrm{L})$ in $100 \mu \mathrm{L}$ Neurobasal medium were combined and incubated for $30 \mathrm{~min}$. After the addition of $150 \mu \mathrm{L}$ of complete Neurobasal medium containing B27 supplement, the mix was applied onto the neuronal culture for $3 \mathrm{~h}$ at $37^{\circ} \mathrm{C}$. Receptor expression was allowed in growth medium for $24 \mathrm{~h}$ after transfection.

\section{Preparation of membranes}

Transfected LLC-PK1 cells were washed with D-PBS, scraped into Tris buffer $\left(10 \mathrm{~mm}\right.$ Tris- $\mathrm{HCl}, \mathrm{pH} 7.7$, for $\left[{ }^{135} \mathrm{I}\right]-\mathrm{CYP}$ binding experiments or $50 \mathrm{~mm}$ Tris- $\mathrm{HCl}, \mathrm{pH} 7.4$, for all other experiments) and homogenized with a Polytron. After each of four successive washings in Tris buffer, the membranes were collected by centrifugation at $31000 \times \boldsymbol{g}$ for $20 \mathrm{~min}$ at $4^{\circ} \mathrm{C}$. An incubation for $10 \mathrm{~min}$ at $37^{\circ} \mathrm{C}$ was performed after the first wash to eliminate 5-HT (from the serum in the culture medium), and the final pellet was suspended in the same Tris buffer to be stored at $-80^{\circ} \mathrm{C}$ until use. Protein concentration was measured using BCA protein assay kit (Pierce).

\section{Radioligand-binding assays}

LSD competition binding assays were performed with $15-30 \mu \mathrm{g}$ of membrane proteins in $500 \mu \mathrm{L}$ of $50 \mathrm{~mm}$ Tris- $\mathrm{HCl}(\mathrm{pH}$ 7.4) supplemented with $1.6 \mathrm{nM}\left[{ }^{3} \mathrm{H}\right] \mathrm{LSD}(79.2 \mathrm{Ci} / \mathrm{mmol})$ and various concentrations of $5-\mathrm{CT}$. Incubations were performed for $90 \mathrm{~min}$ at $25^{\circ} \mathrm{C}$. Assays were stopped by rapid filtration through Whatman GF/B filters that had been coated with polyethylenimine $(0.5 \% \mathrm{vol} / \mathrm{vol})$.

I-CYP competition binding assays were performed with 15-30 $\mu \mathrm{g}$ of membrane proteins in $250 \mu \mathrm{L}$ of $10 \mathrm{~mm}$ Tris $-\mathrm{HCl}(\mathrm{pH}$ 7.7) containing $10 \mu \mathrm{M}$ pargyline, $3 \mu \mathrm{m}$ Isoproterenol, 4 mm MgCl 2,1 nM ${ }^{125}$-CYP (2000 Ci/mmol) and various concentrations of agonist naratriptan or antagonist GR127935. Incubations were performed for $60 \mathrm{~min}$ at $37^{\circ} \mathrm{C}$. Assays were stopped by rapid filtration through Whatman GF/B filters.

For all radioligand binding experiments, non-specific binding was determined in the presence of $30 \mu \mathrm{M} 5-\mathrm{HT}$. Subsequent washing, counting of entrapped radioactivity and calculations of relevant binding parameters were as described (62).

\section{${ }^{35}$ S $] G T P \gamma S$-binding assays}

${ }^{35}$ S]GTP $\mathrm{S}$ binding onto membranes from transfected LLC-PK1 cells was measured according to a procedure adapted from Alper and Nelson (63) and Fabre et al. (64). Briefly, membranes ( $40-50 \mu \mathrm{g}$ protein) were incubated for $30 \mathrm{~min}$ at $37^{\circ} \mathrm{C}$ in a final volume of $800 \mu \mathrm{L}$ assay buffer $(50 \mathrm{~mm}$ Tris- $\mathrm{HCl}$, pH 7.4, $3 \mathrm{~mm} \mathrm{MgCl}$, $120 \mathrm{~mm} \mathrm{NaCl}, 0.2 \mathrm{~mm}$ EGTA) containing $0.1 \mathrm{~nm}\left[{ }^{35} \mathrm{~S}\right] \mathrm{GTP} \gamma \mathrm{S}(1000 \mathrm{Ci} / \mathrm{mmol}$, Amersham Biosciences), $300 \mu \mathrm{M}$ GDP with or without addition of $5-\mathrm{HT}_{1 \mathrm{~A}} \mathrm{R}$ or $5-\mathrm{HT}_{1 \mathrm{~B}} \mathrm{R}$ ligands. The reaction was terminated by addition of $3 \mathrm{~mL}$ ice-cold $50 \mathrm{~mm}$ Tris buffer and rapid vacuum filtration through Whatman GF/B filters. Each filter was then washed twice with $3 \mathrm{~mL}$ ice-cold Tris buffer, placed into $4.5 \mathrm{~mL}$ scintillation fluid and its entrapped radioactivity measured. Basal $\left[{ }^{35}\right.$ S]GTP $\gamma$ S binding was determined from samples without drug.

\section{Microscopy}

Images were taken on a Leica TCS-400 laser-scanning confocal microscope with an oil-immersion 100x, numerical aperture (NA) 1.4 objective, and on a Leica TCS NT laser-scanning confocal microscope with dry 20x, NA 
0.7, oil-immersion 40x, NA 1.2, and oil-immersion 63x, NA 1.4 objectives. Widefield images were taken on a Leica DM-R with dry $20 \times$, NA 0.7, and $40 \times$, NA 0.75, and oil-immersion 100x, NA 1.4 objectives. In all cases, emission and excitation filters proper to each fluorophore were used sequentially and the absence of cross-talk between different channels was checked with selectively labeled preparations.

For receptor distribution assays in cell lines, images of individual cells were obtained by the use of a $100 x$, NA 1.4 oil-immersion objective and $2.5 x$ zoom, resulting in a pixel size of $39.06 \mathrm{~nm}$ for LLC-PK1 cells, or a $63 \times$, NA 1.4 oil-immersion objective and $4 \times$ zoom, resulting in a pixel size of $38.75 \mathrm{~nm}$ for HeLa and COS-7 cells. Cells were randomly chosen with phenotypic consideration to avoid dead, dividing or highly GFP-receptor over-expressing cells. In our protocol, cells were fixed $2.5 \mathrm{~h}$ after seeding, when they displayed a near-spherical form that allowed precise equatorial optical sectioning for reliable quantification.

\section{Receptor distribution assays in cell lines}

Transfected LLC-PK1, COS-7 and HeLa cells were transferred to 12mm-diameter coverslips and assayed as described previously (65) with modifications. Briefly, after a 1-h preincubation with $70 \mu \mathrm{m}$ cycloheximide, cells were incubated with or without ligands for 90 min. M $\beta C D$ treatments were done only during the last $60 \mathrm{~min}$ of incubation. Cells were then washed in D-PBS+ (D-PBS containing $0.1 \mathrm{~mm} \mathrm{CaCl}_{2}$ and $0.1 \mathrm{~mm} \mathrm{MgCl} 2$ ), fixed with paraformaldehyde (3\%) containing $4 \%$ sucrose, treated for $3 \mathrm{~min}$ with $1 \mu \mathrm{g} / \mathrm{mL}$ propidium iodide for nuclear staining and mounted in Fluoromount-G solution (Clinisciences).

Quantification of the subcellular distribution of transfected constructs was as described previously (13). We used in-house-developed macroalgorithms (available on request), written for the public domain OBJECT IMAGE software (available on the World Wide Web at simon.bio.uva.nl/objectimage.html). We measured mean fluorescence density values $S, C$ and $N$, corresponding to the surface (measured from the edge of the cell to $300 \mathrm{~nm}$ inside), cytoplasm and nucleus of the cell, respectively. The nuclear fluorescence $N$, corresponding to the background, was subtracted from the $S$ and $C$ values, which, once multiplied by the respective areas, yielded the $S^{\prime}$ and $C^{\prime}$ total specific fluorescence. The displayed result is the $S^{\prime} / C^{\prime}$ ratio that we call the MFR.

\section{Receptor distribution assays in hippocampal neurons} For surface detection of receptors, anti-Flag M2 antibody $(2.5 \mu \mathrm{g} / \mathrm{mL})$ was added to living cells for $5 \mathrm{~min}$. Cells were washed in D-PBS+, fixed with paraformaldehyde $(4 \%)$ containing $4 \%$ sucrose and incubated for $1 \mathrm{~h}$ with Alexa-Fluor ${ }^{\circledR} 488$-conjugated goat anti-mouse IgG. Quantification of receptor polarization was done as described previously (11) with some modifications. Briefly, $20 \times$ images (from the red and green channels - morphological marker and surface receptor labeling, respectively) of transfected neurons were used. Previously, we have carefully analyzed the distribution of the somatodendritic marker MAP2 (Figure S1) and the axonal marker Tau in our cultures, and now we are able to differentiate between axons and dendrites by using morphological criteria derived from these observations. Segments of neurons were traced along morphologically identified axon and dendrites on soluble DsRed images which show the entire neuronal structure, using the IMAGEJ plugin NeuronJ (http://rsb.info.nih.gov/ij/). Then these segments were transferred to the surface-labeled image, and the axon/dendrite ratio (A/D ratio) was computed from the mean fluorescence of surface labeling along these segments after normalization by subtraction of background. Typically, axonal proteins have $a>1 \mathrm{~A} / \mathrm{D}$ ratio, whereas a somatodendritic distribution leads to a $<1 \mathrm{~A} / \mathrm{D}$ ratio (5).

Analysis of receptor distribution in transfected neuronal populations was done by systematic classification of all transfected neurons, based on the surface receptor distribution, into one of the three categories (in brackets we show the corresponding normalized A/D ratio for each category, mean \pm SEM, pooled from three independent control experiments, $n=262)$ : (i) predominantly somatodendritic $(0.49 \pm 0.02)$, (ii) uniform $(0.67 \pm 0.03)$ and (iii) axonal, without significant somatodendritic labeling $(1.93 \pm 0.05)$. Classification was done blind by a researcher unaware of the experimental condition, by counting all transfected neurons from a coverslip (70-160 neurons) for each condition.

\section{Measure of membrane insertion kinetics of newly synthesized receptors}

Neurons were co-transfected as described above with Flag-5- $\mathrm{HT}_{1 \mathrm{~B}}$ or FlagAba and soluble DsRed. After $3 \mathrm{~h}$, the transfection medium was removed and BFA was added to a final concentration of $0.75 \mu \mathrm{g} / \mathrm{mL}$. After $16-18 \mathrm{~h}$, coverslips were washed three times in conditioned medium and incubated with conditioned medium, either with vehicle (0.2\% DMSO) or inverse agonist (SB224289 or methiothepin, respectively; $5 \mu \mathrm{M}$ ). Coverslips were removed and fixed at indicated times, and stained for surface receptors with anti-Flag M2 antibody as described above. Classification of the membrane distribution of newly synthesized receptors was done as described above.

\section{Measure of constitutive endocytosis by live antibody feeding}

Anti-Flag M2 antibody ( $1 \mu \mathrm{g} / \mathrm{mL}$ ) was first pre-coupled with goat anti-mouse Alexa-Fluor ${ }^{\circledR} 488$ antibody $(2 \mu \mathrm{g} / \mathrm{mL})$ in serum-free neurobasal medium for $1 \mathrm{~h}$ at room temperature. Then, live transfected cells were fed for $1 \mathrm{~h}$ with this mixture at $37^{\circ} \mathrm{C}$. After this first incubation, cells were washed three times with cold D-PBS $+\left(4^{\circ} \mathrm{C}\right)$ and incubated for $1 \mathrm{~h}$ at $4^{\circ} \mathrm{C}$ with anti-goat Alexa-Fluor ${ }^{\circledR} 568$ antibody before fixation. Using this approach, receptors which were accessible at the cell surface during the first 1-h incubation period at $37^{\circ} \mathrm{C}$ were labeled in green. Therefore, the green label identifies two receptor populations, those that were endocytosed and those that remained at the cell surface, while only receptors remaining at the cell surface are co-labeled in red (resulting in yellow on the overlay image) during the second incubation period at $4{ }^{\circ} \mathrm{C}$, a non-permissive temperature for endocytosis. For quantification, widefield $20 \times$ images of 20-44 neurons from at least two experiments were used. The somatodendritic compartment was selected on the red channel and the integrated density of both green and red channels in this compartment were measured using IMAGEJ. To standardize results, the $R / G$ ratio was normalized so that its maximum theoretical value in each experiment is 1 , corresponding to a hypothetical $0 \%$ internalization. The ratio of the red and green label indicates the relative percentage of receptor endocytosis, obtained using the following formula: $100 \times(1-R / G)$.

\section{Statistical analysis}

Data were analyzed using GRAPHPAD PRISM and MATLAB (MathWorks) softwares.

The significance of differences in mean was calculated using Student's t-test, or with one-way ANOva followed by Newman-Keuls post-tests for p-value adjustment, when appropriate. The comparison of neuronal surface distribution for pairs of receptors or chimeras was performed using Pearson's $\chi^{2}$ homogeneity test on the corresponding $4 \times 2$ contingency tables (there are four surface classes: uniform, axonal, somatodendritic, no labeling), the $\chi^{2}$ statistic having hence three degrees of freedom. For significance symbols, 'ns' means $p>0.05$, one symbol means $p<0.05$, two means $p<0.01$ and three means $p<0.001$.

PCA was used to compare the surface distribution of larger sets of receptors and chimeras and analyze the progression of distribution during membrane insertion kinetics assays. The descriptors of the receptors and chimeras were the percentages of the four surface classes, and the principal components were computed on their covariance matrix (66). The projection was made onto the subspace spanned by the first two principal components, and the percentage of the total variance they account for 


\section{Carrel et al.}

was systematically computed and shown in parenthesis on the PCA plots. The fact that their sum was always close to $100 \%$ indicates that only a negligible amount of information was lost by using two components only.

The identification of clusters among the receptors and chimeras was done using K-means analysis (66). Receptors and chimeras were again described by the percentages of the four surface classes that were centered prior to the computation of the distances. The distance used was the squared Euclidean distance and the K-means algorithms were run five times with initializations of the means on randomly chosen receptors. The choice of $K=3$ clusters was validated by a Silhouette value analysis (67). For each sample, the silhouette value attributed to each sample is a measure of his similarity with his own cluster as compared to the other clusters. Too small (or even negative) silhouette negative values indicate that samples resemble more a neighbor cluster than its own one, and hence $K$ is either too small or too large.

A linear relationship between the level of endocytosis and the surface distribution was estimated on the set of the 14 receptors and chimeras by linear regression. To account for the fact that the endocytosis variance was different from one receptor to another (see Figure 7F), and that the mean endocytosis values were obtained on with different numbers of cells for each receptor, the parameter estimation was performed using weighted least squares (68).

\section{Acknowledgments}

This work was funded by grants from INSERM, CNRS and the Agence Nationale pour la Recherche (Z. L., ANR-09-MNPS-004-01). D. C. was supported by fellowships from the Fondation pour la Recherche Médicale and the Fonds AXA pour la Recherche. A. S. was supported by fellowships from the French Ministère de la Recherche and the Association pour la Recherche contre le Cancer. We are grateful to Dr Ursula Rescher (Institute for Medical Biochemistry, Münster, Germany) for her kind gift of the eYFP-p11 construct.

\section{Supporting Information}

Additional Supporting Information may be found in the online version of this article:

Figure S1: Morphological identification of axons and dendrites for A/D quantification. Flag-5- $\mathrm{HT}_{1 \mathrm{~A}}(\mathrm{~A})$ or Flag-5- $\mathrm{HT}_{1 \mathrm{~B}}(\mathrm{~B})$ receptors were co-transfected with soluble DsRed (red), and surface-localized 5-HT receptors (green) were detected in live cells with M2 anti-Flag antibody after $24 \mathrm{~h}$ of expression. MAP2 labeling (blue) performed after fixation and permeabilization allowed us to distinguish the dendrites (MAP2 positive, arrowheads) from the axon (MAP2 negative, arrows). C) The normalized percentage of endocytosis in the somatodendritic compartment of individual neurons does not depend on the expression level of Flag$5 \mathrm{HT}_{1 \mathrm{~A}}$ and $5-\mathrm{HT}_{1 \mathrm{~B}}$ receptors in each particular neuron. Indeed, there is no correlation between the value of total anti-Flag (endocytosed + surface) mean fluorescence and the mean of endocytosis (\%) from 33 to 49 neurons (from at least three independent experiments, $r^{2}=0.06$ for $5-\mathrm{HT}_{1 \mathrm{~A}} \mathrm{R}$ and $r^{2}=0.09$ for $5-H_{1 B} R$ ). This implies that constitutive endocytosis of 5 HTR does not depend on variation in expression levels between individual neurons or between experimental conditions.

Figure S2: Inhibition of neuronal endocytosis shifts surface expression of $5-\mathrm{HT}_{1 \mathrm{~B}} \mathrm{R}$ from the axon to the soma and dendrites. Hippocampal neurons at DIV7 were co-transfected with soluble DsRed, Flag-5-HT $1 \mathrm{~B}$ and a fusion of eCFP (blue) with various proteins: inactive mutant eps15(III $\Delta 2$ )

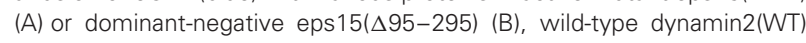
(C) or dominant-negative dynamin2(K44A) (D). Twenty-four hours later, they were stained for surface $5-\mathrm{HT}_{1 \mathrm{~B}} \mathrm{R}$ (green) and fixed. WT or inactive proteins did not change polarization of $5-\mathrm{HT}_{1 \mathrm{~B}} \mathrm{R}$ surface expression (green labeling, A, C), whereas dominant-negative mutants of eps15 and dyn2 strongly upregulated expression of $5-\mathrm{HT}_{1 \mathrm{~B}} \mathrm{R}$ at the somatodendritic surface (B and D). On overlay images, blue represents nuclei. Scale bar: $50 \mu \mathrm{m}$.
Figure S3: Functional properties of GFP-coupled receptors. A) Ligandbinding properties of GFP-coupled receptors. Left panel, concentration curves of the inhibition by $5-C T$ of $\left[{ }^{3} \mathrm{H}\right] \mathrm{LSD}$-specific binding to membranes from transfected LLC-PK1 cells expressing 5-HT 1 A (•) or 5-HT $1 \mathrm{~A}^{-\mathrm{eGFP}}(0)$ receptor. Assays were performed with $1.6 \mathrm{~nm}\left[{ }^{3} \mathrm{H}\right] \mathrm{LSD}$ and various concentrations (abscissa) of 5-CT. Middle and right panels, concentration curves of the inhibition by GR127935 (middle) or naratriptan (right) of [135 I]-CYPspecific binding to membranes from transfected LLC-PK1 cells expressing $5-\mathrm{HT}_{1 \mathrm{~B}}(\square)$ or $5-\mathrm{HT}_{1 \mathrm{~B}}-\mathrm{eGFP}(\square)$ receptor. Assays were performed with $1 \mathrm{~nm}\left[{ }^{135} \mathrm{I}\right]-\mathrm{CYP}$ and various concentrations (abscissa) of GR127935 or naratriptan. In all cases, the apparent Hill coefficient was close to 1.0. B) $\left[{ }^{35}\right.$ S ] GTP $\gamma$ S binding to membranes from LLC-PK1 cells expressing $5-H_{1} T_{1}$, $5-\mathrm{HT}_{1 \mathrm{~A}}$-eGFP, $5-\mathrm{HT}_{1 \mathrm{~B}}$ or $5-\mathrm{HT}_{1 \mathrm{~B}}$-eGFP receptors. Binding was stimulated by the agonist $5-C T(1 \mu \mathrm{M}$, black bars) or inhibited by an inverse agonist (methiothepin or SB224289, $10 \mu \mathrm{M}$, gray bars). Basal binding determined in the absence of ligand was set to $100 \%$ (white bars). Mean \pm SEM of at least two independent experiments performed in triplicate. ${ }^{* *} p<0.001$ for significance of difference between 5-CT or inverse-agonist treatment and basal; ns, non-significant.

Figure S4: Characterization of receptor chimeras. A) Positions of the unique $E c o R I$ and $A c / l$ sites inserted into the rat cDNA sequence of 5-HT $1 A$ and 5-HT $1 B$ R (accession numbers NM_012585.1 and NM_022225.1, respectively) to construct 5- $\mathrm{HT}_{1} / 5-\mathrm{HT}_{1 \mathrm{~B}}$ chimeras and details of the substitutions introduced to obtain these sites. B) Schematic representation of the chimeras $\mathrm{Aab}$ and $\mathrm{Abb}$ that were not functional, with $5-\mathrm{HT}_{1 \mathrm{~A}} \mathrm{R}$ parts in gray and $5-\mathrm{HT}_{1 \mathrm{~B}} \mathrm{R}$ parts in black. C) Flag-Bab, FlagBaa and Flag-Bba chimeras were co-transfected with soluble DsRed (red) and surface-localized chimeras (green) were detected in live cells with anti-Flag M2 antibody. Bab and Baa chimeras are mainly localized at the somatodendritic surface (arrowheads), whereas Bba is mainly localized at the axonal surface of neurons (arrows). Scale bar: $20 \mu \mathrm{m}$. D) Quantification of surface distribution of Flag-Bab, Flag-Baa, Flag-Bba and Flag-Aba after $24 \mathrm{~h}$ of expression in transfected neurons (distribution of Flag-5-HT $1 \mathrm{~A}$ and Flag-5- $\mathrm{HT}_{1 \mathrm{~B}}$ receptors are reminded from Fig. 1). E) Quantification of endocytosis of Flag-Bab, Flag-Baa, Flag-Bba and Flag-Aba. On overlay images, blue represents nuclei.

Figure S5: Surface distribution kinetics of the Aba chimera in neurons treated either par vehicle or the inverse-agonist methiothepin. PCA plot of the surface distribution of Aba chimera for each time-point of both vehicle and methiothepin treatments and for vehicle treatment in the absence of incubation with BFA (control). Tendency curves have been drawn to show the evolution of distribution for both treatment conditions.

Figure S6: p11 overexpression does not enhance plasma membrane targeting of $5-\mathrm{HT}_{1 \mathrm{~B}}$ receptors in HeLa and COS-7 cells. A) Confocal images of equatorial sections of near-spherical HeLa or COS-7 cells, transfected either with eYFP-p11 or 5- $\mathrm{HT}_{1 \mathrm{~B}}-\mathrm{HcR}_{\mathrm{c}}$ ed. B) Confocal images of equatorial sections of near-spherical HeLa or COS-7 cells, co-transfected with both eYFP-p11 and 5-HT $1 \mathrm{~B}^{-\mathrm{HcR}}$ ed. Overlay fails to reveal colocalization

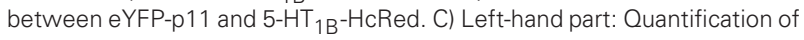
eYFP-p11 MFR with or without the coexpression of 5-HT $1 \mathrm{~B}-\mathrm{H}_{c}$ Red receptor; right-hand part: quantification of $5-\mathrm{HT}_{1 \mathrm{~B}}-\mathrm{HcR}_{\mathrm{C}} \mathrm{R}$ MFR with or without the coexpression of eYFP-p11. Results, expressed as mean \pm SEM, are representative of two independent experiments. Expression of eYFP-p11 in HeLa or COS-7 cells does not appear to direct 5-HT $1 \mathrm{~B}-\mathrm{HcR}_{\mathrm{C}}$ ed receptors to the surface membrane. ${ }^{*} p<0.05$ for significance of difference between COS-7 cells expressing eYFP-p11 with $5-\mathrm{HT}_{1 \mathrm{~B}}-\mathrm{HcR}_{\mathrm{H}}$ ed versus without $5-\mathrm{HT}_{1 \mathrm{~B}}-\mathrm{HcR}_{\mathrm{C}}$ and ${ }^{*} \mathrm{p}<0.01$ for significance of difference between COS-7 cells expressing $5-\mathrm{HT}_{1 \mathrm{~B}}-\mathrm{HcR}_{\mathrm{C}}$ ed with eYFP-p11 versus without eYFP-p11.

Table S1. Composition of the $5-H T_{1 A} R / 5-H T_{1 B} R$ chimeric sub-l3 loops. The length of each loop as well as the positions of the regions of $5-H_{1} T_{1 A}$ and $5-H_{1 B} R$ I3 loops (I3a1-3 and I3b1-2, respectively) used for each chimera in the rat cDNA sequences of $5-\mathrm{HT}_{1 \mathrm{~A}} \mathrm{R}$ and $5-\mathrm{HT}_{1 \mathrm{~B}} \mathrm{R}$ (accession numbers NM_012585.1 and NM_022225.1, respectively) are presented.

Please note: Wiley-Blackwell are not responsible for the content or functionality of any supporting materials supplied by the authors. Any queries (other than missing material) should be directed to the corresponding author for the article. 


\section{Constitutive Endocytosis Targets $5-\mathrm{HT}_{1 \mathrm{~B}} \mathrm{R}$ to Axons}

\section{References}

1. Winckler B, Forscher P, Mellman I. A diffusion barrier maintains distribution of membrane proteins in polarized neurons. Nature 1999:397:698-701.

2. Nakada C, Ritchie K, Oba Y, Nakamura M, Hotta $Y$, lino R, Kasai RS, Yamaguchi K, Fujiwara T, Kusumi A. Accumulation of anchored proteins forms membrane diffusion barriers during neuronal polarization. Nat Cell Biol 2003;5:626-632.

3. Burack MA, Silverman MA, Banker G. The role of selective transport in neuronal protein sorting. Neuron 2000;26:465-472.

4. Garrido JJ, Fernandes F, Giraud P, Mouret I, Pasqualini E, Fache MP, Jullien F, Dargent B. Identification of an axonal determinant in the C-terminus of the sodium channel $\mathrm{Na}(\mathrm{v}) 1.2$. Embo J 2001;20: 5950-5961.

5. Sampo B, Kaech S, Kunz S, Banker G. Two distinct mechanisms target membrane proteins to the axonal surface. Neuron 2003:37:611-624.

6. Wisco D, Anderson ED, Chang MC, Norden C, Boiko T, Folsch $\mathrm{H}$, Winckler $\mathrm{B}$. Uncovering multiple axonal targeting pathways in hippocampal neurons. J Cell Biol 2003;162:1317-1328.

7. Yap CC, Nokes RL, Wisco D, Anderson E, Folsch H, Winckler B. Pathway selection to the axon depends on multiple targeting signals in NgCAM. J Cell Sci 2008;121:1514-1525.

8. Lasiecka ZM, Yap CC, Vakulenko M, Winckler B. Compartmentalizing the neuronal plasma membrane from axon initial segments to synapses. Int Rev Cell Mol Biol 2009;272:303-389.

9. Kobilka BK, Deupi X. Conformational complexity of G-protein-coupled receptors. Trends Pharmacol Sci 2007;28:397-406.

10. Hanyaloglu AC, von Zastrow M. Regulation of GPCRs by endocytic membrane trafficking and its potential implications. Annu Rev Pharmacol Toxicol 2008;48:537-568.

11. Leterrier C, Laine J, Darmon M, Boudin H, Rossier J, Lenkei Z. Constitutive activation drives compartment-selective endocytosis and axonal targeting of type 1 cannabinoid receptors. J Neurosci 2006;26: 3141-3153

12. Holliday ND, Holst B, Rodionova EA, Schwartz TW, Cox HM. Importance of constitutive activity and arrestin-independent mechanisms for intracellular trafficking of the ghrelin receptor. Mol Endocrinol 2007;21:3100-3112.

13. Leterrier C, Bonnard D, Carrel D, Rossier J, Lenkei Z. Constitutive endocytic cycle of the $\mathrm{CB}_{1}$ cannabinoid receptor. J Biol Chem 2004; 279:36013-36021.

14. Marion S, Weiner DM, Caron MG. RNA editing induces variation in desensitization and trafficking of 5-hydroxytryptamine 2c receptor isoforms. J Biol Chem 2004;279:2945-2954.

15. McCune DF, Edelmann SE, Olges JR, Post GR, Waldrop BA, Waugh DJ, Perez DM, Piascik MT. Regulation of the cellular localization and signaling properties of the alpha(1B)- and alpha(1D)-adrenoceptors by agonists and inverse agonists. Mol Pharmacol 2000;57:659-666.

16. Pula G, Mundell SJ, Roberts PJ, Kelly E. Agonist-independent internalization of metabotropic glutamate receptor $1 \mathrm{a}$ is arrestin- and clathrin-dependent and is suppressed by receptor inverse agonists. J Neurochem 2004;89:1009-1020.

17. Tarasova NI, Stauber $\mathrm{RH}$, Choi JK, Hudson EA, Czerwinski G, Miller $\mathrm{JL}$, Pavlakis GN, Michejda CJ, Wank SA. Visualization of G proteincoupled receptor trafficking with the aid of the green fluorescent protein. Endocytosis and recycling of cholecystokinin receptor type A. J Biol Chem 1997:272:14817-14824.

18. McDonald NA, Henstridge CM, Connolly CN, Irving AJ. An essential role for constitutive endocytosis, but not activity, in the axonal targeting of the CB1 cannabinoid receptor. Mol pharmacol 2007;71: 976-984.

19. Engel G, Gothert M, Hoyer D, Schlicker E, Hillenbrand K. Identity of inhibitory presynaptic 5-hydroxytryptamine (5-HT) autoreceptors in the rat brain cortex with $5-\mathrm{HT}_{1 \mathrm{~B}}$ binding sites. Naunyn Schmiedebergs Arch Pharmacol 1986;332:1-7

20. Gaspar P, Cases O, Maroteaux L. The developmental role of serotonin: news from mouse molecular genetics. Nat Rev Neurosci 2003;4: 1002-1012

21. Barnes NM, Sharp T. A review of central 5-HT receptors and their function. Neuropharmacology 1999;38:1083-1152.
22. Haj-Dahmane $S$, Hamon $M$, Lanfumey L. $\mathrm{K}^{+}$channel and 5-hydroxytryptamine1A autoreceptor interactions in the rat dorsal raphe nucleus: an in vitro electrophysiological study. Neuroscience 1991;41:495-505.

23. Boschert $U$, Amara DA, Segu L, Hen R. The mouse 5-hydroxytryptamine1B receptor is localized predominantly on axon terminals. Neuroscience 1994;58:167-182.

24. Doucet E, Pohl M, Fattaccini CM, Adrien J, Mestikawy SE, Hamon M. In situ hybridization evidence for the synthesis of $5-\mathrm{HT}_{1 \mathrm{~B}}$ receptor in serotoninergic neurons of anterior raphe nuclei in the rat brain. Synapse 1995;19:18-28.

25. Kia HK, Miquel MC, Brisorgueil MJ, Daval G, Riad M, El Mestikawy S, Hamon M, Vergé D. Immunocytochemical localization of serotonin1A receptors in the rat central nervous system. J Comp Neurol 1996;365:289-305.

26. Sari Y, Miquel MC, Brisorgueil MJ, Ruiz G, Doucet E, Hamon M, Vergé D. Cellular and subcellular localization of 5-hydroxytryptamine $1 \mathrm{~B}$ receptors in the rat central nervous system: immunocytochemical, autoradiographic and lesion studies. Neuroscience 1999;88:899-915.

27. Riad M, Garcia S, Watkins KC, Jodoin N, Doucet E, Langlois X, El Mestikawy S, Hamon M, Descarries L. Somatodendritic localization of $5-\mathrm{HT}_{1 \mathrm{~A}}$ and preterminal axonal localization of $5-\mathrm{HT}_{1 \mathrm{~B}}$ serotonin receptors in adult rat brain. J Comp Neurol 2000;417:181-194.

28. Darmon $M$, Langlois $X$, Suffisseau L, Fattaccini CM, Hamon $M$. Differential membrane targeting and pharmacological characterization of chimeras of rat serotonin $5-\mathrm{HT}_{1 \mathrm{~A}}$ and $5-\mathrm{HT}_{1 \mathrm{~B}}$ receptors expressed in epithelial LLC-PK1 cells. J Neurochem 1998;71:2294-2303.

29. Jolimay N, Franck L, Langlois X, Hamon M, Darmon M. Dominant role of the cytosolic $\mathrm{C}$-terminal domain of the rat $5-\mathrm{HT}_{1 \mathrm{~B}}$ receptor in axonal-apical targeting. J Neurosci 2000;20:9111-9118.

30. Ascano M, Richmond A, Borden P, Kuruvilla R. Axonal targeting of Trk receptors via transcytosis regulates sensitivity to neurotrophin responses. J Neurosci 2009;29:11674-11685.

31. Bel C, Oguievetskaia K, Pitaval C, Goutebroze L, Faivre-Sarrailh C. Axonal targeting of Caspr2 in hippocampal neurons via selective somatodendritic endocytosis. J Cell Sci 2009;122:3403-3413.

32. Benmerah A, Poupon V, Cerf-Bensussan N, Dautry-Varsat A. Mapping of Eps15 domains involved in its targeting to clathrin-coated pits. J Biol Chem 2000;275:3288-3295.

33. Cao H, Garcia F, McNiven MA. Differential distribution of dynamin isoforms in mammalian cells. Mol Biol Cell 1998;9:2595-2609.

34. Carrel D, Hamon M, Darmon M. Role of the C-terminal di-leucine motif of $5-\mathrm{HT}_{1 \mathrm{~A}}$ and $5-\mathrm{HT}_{1 \mathrm{~B}}$ serotonin receptors in plasma membrane targeting. J Cell Sci 2006;119:4276-4284.

35. Subtil A, Gaidarov I, Kobylarz K, Lampson MA, Keen JH, McGraw TE. Acute cholesterol depletion inhibits clathrin-coated pit budding. Proc Natl Acad Sci U S A 1999:96:6775-6780.

36. Cossec JC, Simon A, Marquer C, Moldrich RX, Leterrier C, Rossier J, Duyckaerts C, Lenkei Z, Potier MC. Clathrin-dependent APP endocytosis and Abeta secretion are highly sensitive to the level of plasma membrane cholesterol. Biochim Biophys Acta 2010;1801: 846-852.

37. Newman-Tancredi A, Audinot V, Moreira C, Verriele L, Millan MJ. Inverse agonism and constitutive activity as functional correlates of serotonin h5-HT(1B) receptor/G-protein stoichiometry. Mol Pharmacol 2000;58:1042-1049

38. Selkirk JV, Scott C, Ho M, Burton MJ, Watson J, Gaster LM, Collin L, Jones BJ, Middlemiss DN, Price GW. SB-224289-a novel selective (human) $5-\mathrm{HT}_{1 \mathrm{~B}}$ receptor antagonist with negative intrinsic activity. Br J Pharmacol 1998;125:202-208.

39. Boess FG, Martin IL. Molecular biology of 5-HT receptors. Neuropharmacology 1994;33:275-317.

40. Donato R. Functional roles of $\mathbf{S} 100$ proteins, calcium-binding proteins of the EF-hand type. Biochim Biophys Acta 1999;1450:191-231.

41. Svenningsson $P$, Chergui $K$, Rachleff I, Flajolet $M$, Zhang $X$, El Yacoubi M, Vaugeois JM, Nomikos GG, Greengard P. Alterations in $5-\mathrm{HT}_{1 \mathrm{~B}}$ receptor function by $\mathrm{p} 11$ in depression-like states. Science 2006;311:77-80.

42. Carrel D, Masson J, Al Awabdh S, Capra CB, Lenkei Z, Hamon M, Emerit MB, Darmon M. Targeting of the $5-\mathrm{HT}_{1}$ A serotonin receptor to neuronal dendrites is mediated by Yif1B. J Neurosci 2008;28: 8063-8073. 


\section{Carrel et al.}

43. Martel JC, Ormiere AM, Leduc N, Assie MB, Cussac D, NewmanTancredi A. Native rat hippocampal $5-\mathrm{HT}_{1} \mathrm{~A}$ receptors show constitutive activity. Mol Pharmacol 2007;71:638-643.

44. Newman-Tancredi A, Conte C, Chaput C, Verriele L, Millan MJ. Agonist and inverse agonist efficacy at human recombinant serotonin 5-HT1A receptors as a function of receptor:G-protein stoichiometry. Neuropharmacology 1997;36:451-459.

45. Chakir K, Xiang Y, Yang D, Zhang SJ, Cheng H, Kobilka BK, Xiao RP. The third intracellular loop and the carboxyl terminus of beta2adrenergic receptor confer spontaneous activity of the receptor. Mol Pharmacol 2003;64:1048-1058.

46. Schoneberg T, Schultz G, Gudermann T. Structural basis of G proteincoupled receptor function. Mol Cell Endocrinol 1999;151:181-193.

47. Weis WI, Kobilka BK. Structural insights into G-protein-coupled receptor activation. Curr Opin Struct Biol 2008;18:734-740.

48. Lee KB, Ptasienski JA, Pals-Rylaarsdam R, Gurevich V, Hosey MM. Arrestin binding to the $\mathrm{M}(2)$ muscarinic acetylcholine receptor is precluded by an inhibitory element in the third intracellular loop of the receptor. J Biol Chem 2000;275:9284-9289.

49. Peverelli E, Mantovani G, Calebiro D, Doni A, Bondioni S, Lania A, Beck-Peccoz P, Spada A. The third intracellular loop of the human somatostatin receptor 5 is crucial for arrestin binding and receptor internalization after somatostatin stimulation. Mol Endocrinol 2008;22: $676-688$.

50. Granas C, Larhammar D. Identification of an amino acid residue important for binding of methiothepin and sumatriptan to the human 5-HT(1B) receptor. Eur J Pharmacol 1999;380:171-181.

51. Shi L, Javitch JA. The binding site of aminergic G protein-coupled receptors: the transmembrane segments and second extracellular loop. Annu Rev Pharmacol Toxicol 2002;42:437-467.

52. Kenakin T. Functional selectivity through protean and biased agonism: who steers the ship? Mol Pharmacol 2007;72:1393-1401.

53. Palanche T, Ilien B, Zoffmann S, Reck MP, Bucher B, Edelstein SJ, Galzi JL. The neurokinin A receptor activates calcium and CAMP responses through distinct conformational states. J Biol Chem 2001; 276:34853-34861.

54. Urban JD, Clarke WP, von Zastrow M, Nichols DE, Kobilka B, Weinstein $H$, Javitch JA, Roth BL, Christopoulos A, Sexton PM, Miller KJ, Spedding M, Mailman RB. Functional selectivity and classical concepts of quantitative pharmacology. J Pharmacol Exp Ther 2007;320: $1-13$.

55. Peverelli E, Lania AG, Mantovani G, Beck-Peccoz P, Spada A. Characterization of intracellular signaling mediated by human somatostatin receptor 5: role of the DRY motif and the third intracellular loop. Endocrinology 2009;150:3169-3176.
56. Bockaert J, Fagni L, Dumuis A, Marin P. GPCR interacting proteins (GIP). Pharmacol Ther 2004;103:203-221.

57. Wu DF, Koch T, Liang YJ, Stumm R, Schulz S, Schroder H, Hollt V. Membrane glycoprotein $\mathrm{M} 6$ a interacts with the micro-opioid receptor and facilitates receptor endocytosis and recycling. J Biol Chem 2007; 282:22239-22247.

58. Rescher U, Gerke V. Annexins-unique membrane binding proteins with diverse functions. J Cell Sci 2004;117:2631-2639.

59. Albert PR, Zhou OY, Van Tol HH, Bunzow JR, Civelli O. Cloning, functional expression, and mRNA tissue distribution of the rat 5-hydroxytryptamine1A receptor gene. J Biol Chem 1990;265: 5825-5832.

60. Hamblin MW, McGuffin RW, Metcalf MA, Dorsa DM, Merchant KM. Distinct $5-\mathrm{HT}_{1 \mathrm{~B}}$ and $5-\mathrm{HT}_{1 \mathrm{D}}$ serotonin receptors in rat: structural and pharmacological comparison of the two cloned receptors. Mol Cell Neurosci 1992;3:578-587.

61. Langlois X, El Mestikawy S, Arpin M, Triller A, Hamon M, Darmon M. Differential addressing of $5-\mathrm{HT}_{1 \mathrm{~A}}$ and $5-\mathrm{HT}_{1 \mathrm{~B}}$ receptors in transfected LLC-PK1 epithelial cells: a model of receptor targeting in neurons. Neuroscience 1996;74:297-302.

62. Fabre V, Boni C, Mocaer E, Lesourd M, Hamon M, Laporte AM. $\left[{ }^{3} \mathrm{H}\right]$ Alnespirone: a novel specific radioligand of $5-\mathrm{HT}_{1} \mathrm{~A}$ receptors in the rat brain. Eur J Pharmacol 1997;337:297-308.

63. Alper $\mathrm{RH}$, Nelson DL. Characterization of $5-\mathrm{HT}_{1}$ A receptor-mediated $\left[{ }^{35}\right.$ S GTPgammaS binding in rat hippocampal membranes. Eur J Pharmacol 1998;343:303-312.

64. Fabre V, Beaufour C, Evrard A, Rioux A, Hanoun N, Lesch KP, Murphy DL, Lanfumey L, Hamon M, Martres MP. Altered expression and functions of serotonin $5-\mathrm{HT}_{1 \mathrm{~A}}$ and $5-\mathrm{HT}_{1 \mathrm{~B}}$ receptors in knock-out mice lacking the 5-HT transporter. Eur J Neurosci 2000;12:2299-2310.

65. Miserey-Lenkei S, Parnot C, Bardin S, Corvol P, Clauser E. Constitutive internalization of constitutively active agiotensin II AT(1A) receptor mutants is blocked by inverse agonists. J Biol Chem 2002;277: 5891-5901.

66. Johnson RA, Wichern DW. Applied Multivariate Statistical Analysis. 5th Edn. Upper Saddle River: Prentice Hall; 2002.

67. Kaufman L, Rousseeuw PJ. Finding Groups in Data: An Introduction to Cluster Analysis. Hoboken: John Wiley \& Sons, Inc.; 1990.

68. Draper NR, Smith H. Applied Regression Analysis. 3rd Edn. New York: Wiley; 1998.

69. Chenna R, Sugawara H, Koike T, Lopez R, Gibson TJ, Higgins DG, Thompson JD. Multiple sequence alignment with the Clustal series of programs. Nucleic Acids Res 2003;31:3497-3500. 